\title{
Remarks on 40+ Years of Mechanical Engineering Teaching
}

\author{
Paulo M. S. Tavares de Castro \\ Emeritus Professor, University of Porto, Faculty of Engineering, Rua Dr Roberto Frias, 4200- \\ 465 PORTO, Portugal (ptcastro@fe.up.pt) ORCID 0000-0003-3202-1343
}

\section{Author Keywords education. \\ Type: Testimonial \\ ว Open Access \\ $\square$ Peer Reviewed \\ (c)

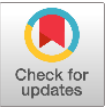

Academic staff career, engineering education, ethics, evaluation, higher

Keynote presentation at the 1 st International Conference on Science and Technology Education (STE 2020), 15-16 October 2020, at FEUP, Porto, Portugal

\begin{abstract}
Having obtained my licenciatura in Mechanical Engineering in 1973, I started an MSc in Applied Mechanics at Imperial College London the year after the carnation revolution in Portugal. Later, I prepared my PhD at Cranfield Institute of Technology (now Cranfield University). After 5 years in the UK, I returned to Porto with my MSc and PhD degrees to start an appointment as assistant professor at FEUP in 1980.

Portugal was then struggling with a radical change of circumstances: from a country with overseas colonies, impoverished by a dictatorship and wars against liberation movements in Africa, to a European country and democracy with a dramatic lack of infrastructure. Research was certainly not a priority!

In 1986 Portugal joined the European Communities, and in 1999 was one of the initial member countries adopting the Euro. Among other setbacks, bad choices of priorities (an excessive emphasis on services with neglect of manufacturing, or heavy investment in motorways with complete neglect of railways) marked the path until todays' situation. Nevertheless, attention dedicated to scientific and technical research grew steadily in the past decades; and 2020 started with the country displaying good prospects as regards financial stability and renewed interest for manufacturing and exports.

Having moved from assistant professor to full professor, with sabbaticals and visiting professorships in several countries, and participation in juries for selection of academic staff in many institutions, I had the possibility of witnessing the transformations in the engineering education scene in Portugal and elsewhere.

The communication will discuss lessons learned throughout my $40+$ years academic career, put in the context of a highly diversified set of external circumstances.
\end{abstract}

\section{Introduction}

This is no research paper, but a bunch of remarks on a long career in academe, recently finished because of the Portuguese requirement for compulsory retirement at 70 . This change in status favours reflection on many facts, notions and events that impressed me in my professional life. Because their number and variety are too large for treatment here, the ruminations offered cover just a selection, hopefully relevant to the intended readership of this journal. To keep within the limits of an article, a quasi 'bullet listing' type of presentation has been adopted. Frequently, recourse will be made to quotations of others that expressed themselves with a clarity I could not aim to achieve; hopefully, the manuscript will survive the 'plagiarism detection' exam, since quoted material is written in italic and dully referenced. 
Portugal finished the dictatorship in 1974, and in 1986 joined the European Communities, now the European Union, EU. From 1975 to 1979 I stayed in the UK, where I got my MSc and DIC from Imperial College and PhD from Cranfield Institute of Technology (now Cranfield University). On my return to Portugal I joined the Faculdade de Engenharia da Universidade do Porto (FEUP) as an assistant professor ('professor auxiliar', the local designation of an entry academic job for a PhD holder). Infrastructure for research in Mechanical Engineering at the Universidade do Porto was almost non-existent in the seventies and early eighties (and the few other areas with adequate research conditions were certainly few and far between at the Universidade do Porto or other Portuguese institutions). Of course myself and the other young new academic staff hired had the mission to contribute to create the conditions to enable research activities. The actual performance of research was hindered by all sort of difficulties. No surprise that the research outcomes were in general poor.

Figure 1 shows R\&D expenditure as a percentage of GDP (all sectors) in Portugal (PORDATA 2019).

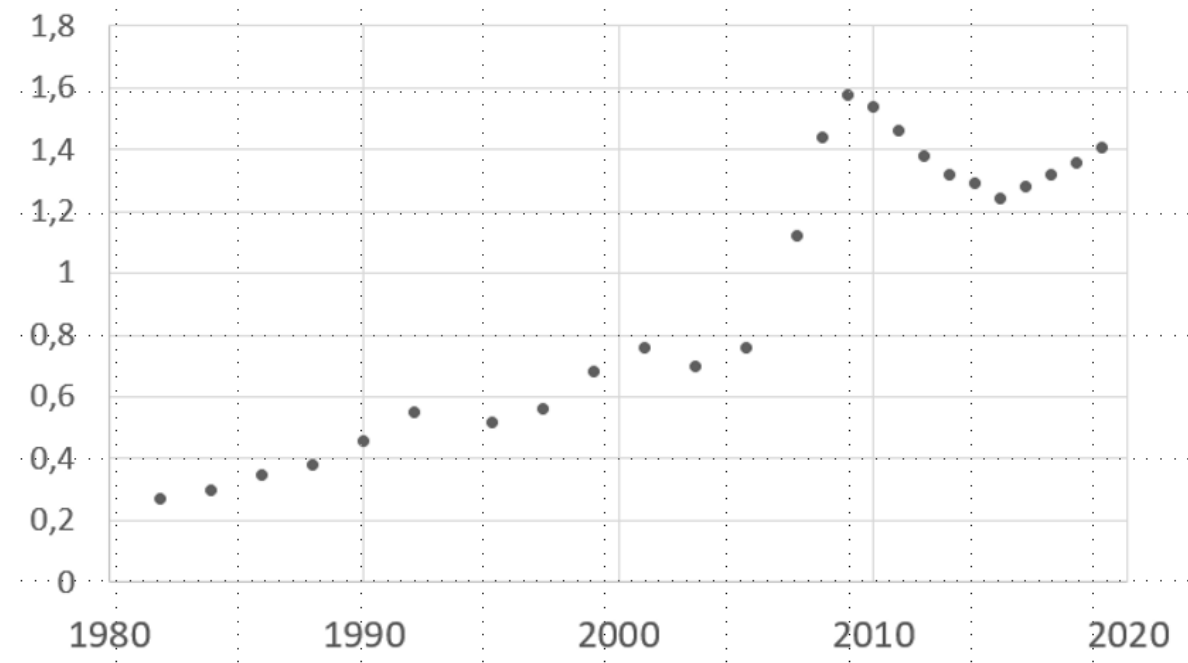

Figure 1: R\&D expenditure as a percentage of GDP (all sectors) in Portugal

A continuous albeit anemic growth is noted between 1982 and 2003; only in 2003-2009 growth was substantial. Then in 2009 came the Eurozone debt crisis and Portugal's loss of access to international capital markets. The subsequent crisis management by the EU, the IMF and the ECB impoverished Portugal ${ }^{1}$ (Schwartz and Takagi 2017; Eichenbaum, Rebelo, and de Resende 2017) to a point that only now the R\&D expenditure is approaching the levels of 2009.

But the question here is the relation between R\&D funds and outcomes. Using myself as guinea pig, Figure 2 illustrates my own outcomes as measured by SCOPUS.

There is no need for mathematics to identify some correlation between Figures 1 and 2 . Research, particularly of an experimental nature, needs funds like omelettes need eggs.

Another aspect of my return from the UK was the need for my involvement in the administration and management of my department. In 1982-1986 I was Director of the Mechanical Engineering degree at FEUP ${ }^{2}$; and in 1987-1990 Head of the Mechanical

\footnotetext{
${ }^{1}$ Nevertheless, a report of IMF states that 'the approach to decision-making adopted had substantial implications for the legitimacy, accountability, and governance of the institution [IMF]. Regarding legitimacy, a significant part of the [IMF] membership felt excluded and thought European countries were treated more favorably' (Schwartz and Takagi 2017, 30).

2 Designation wasthen: 'Coordenador Escolar'.
} 
Engineering Department, appointments that also contribute to explaining the long plateau of Figure 2.

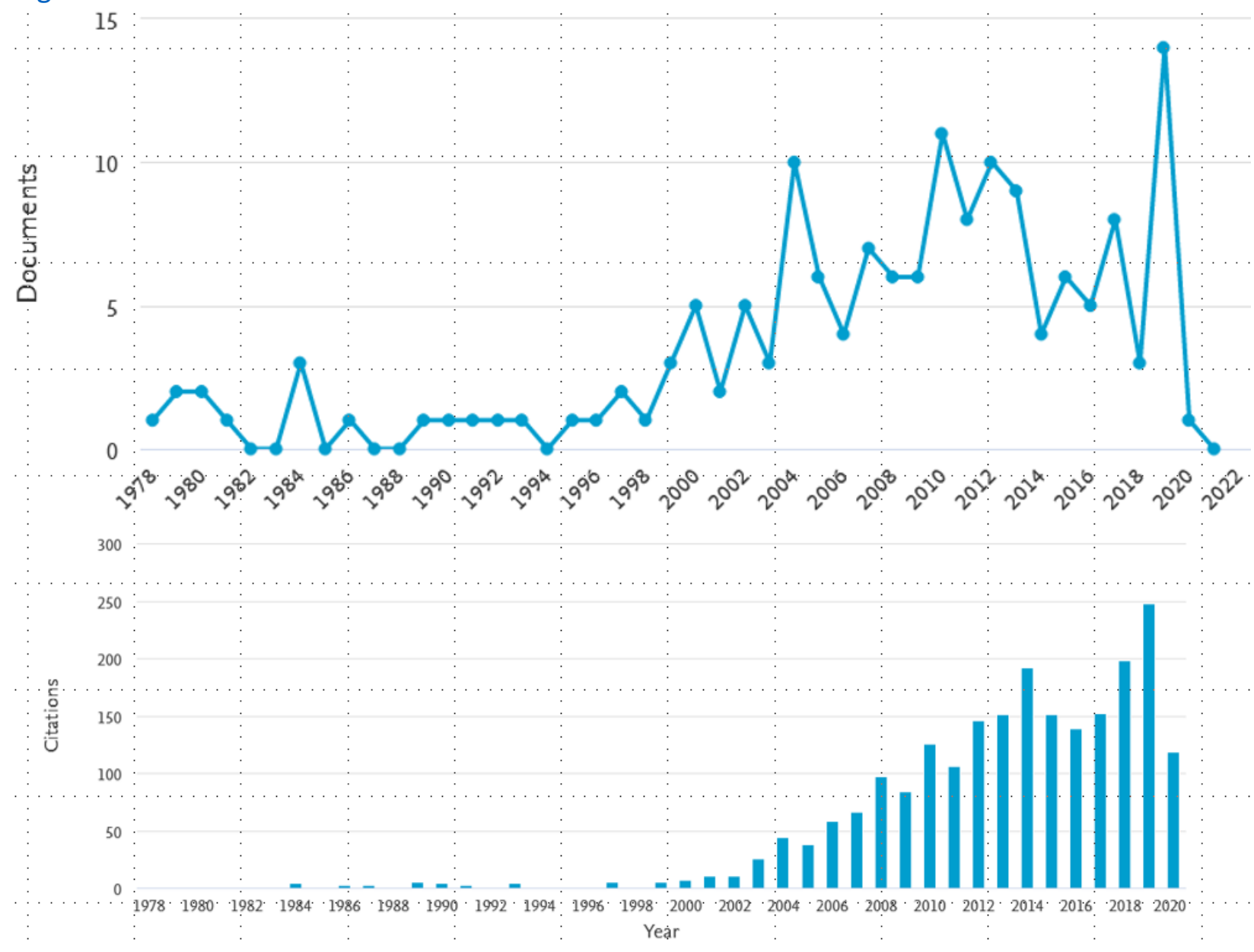

Figure 2: SCOPUS information concerning the author

Young staff such as myself quickly became heavily involved in management duties at our institution. This was a consequence of its fragility, and was aimed at creating conditions for its proper development. But the willingness to serve was a result of the prevailing atmosphere of commonly shared objectives, so persuasively created by Professor Vasco Sá; more about that later.

Involvement in management issues may or may not be gratifying; that depends on the task but also on personal characteristics. From the Wankat and Oreovicz $(1993,339)$ book 'Teaching Engineering', '... some professors may want to include service or administration in their development plans. This is not really a sign of the onset of senility. One of the duties of faculty is to do their fair share in faculty governance .... ; and in p.340, '... A fully functioning department needs faculty who are interested in all areas of research, teaching, engineering practice, service, and administration. [....] many universities [....] expect faculty members to excel at everything. Very few professors can be good in all areas simultaneously. A functioning department needs professors who specialize in one or two. The current problem and challenge for the future is that some areas such as research receive many more rewards than the others. A department can find itself with few professors interested in students, service, engineering practice, or administration. The results can include student revolts, a breakdown in service and a lack of curriculum development, difficulty at accreditation time, and a lack of leadership. Balance is needed but is difficult to maintain for long periods ...'. 
Vasco Sá was a born academic leader, who in the sixties and seventies created and guided in the proper direction the embryo of the Mechanical Engineering Department of FEUP. As Rui Guimarães and myself wrote in his obituary (de Castro and Guimarães 2012), he was characterized by:

- strategic vision based on conceptual clarity, long-term perspective and willingness to reach compromises;

- leadership combined with willingness to delegate, essential characteristics for leading the rapid conversion of a small group of FEUP from fifty years ago into a true university department today (Mechanical Engineering) and the creation of another one (Engineering and Industrial Management);

- great simplicity and modesty, wishing to be always out of the focus of attention;

- perseverance and work capacity;

- availability to revise his opinions (positive or negative) as a result of changes in external conditions or new evidence;

- ethical values, intellectual honesty, good citizenship, solidarity; placing the common interest above the individual interests.

As a young staff member, these qualities of our leader impressed me a lot and certainly shaped my future career. Likewise, some readings raised my awareness of why a career in higher education was an interesting prospect. Among those readings, let me kick-off with two quotations from the Harvard Dean Henry Rosovsky $(1990,88)$ : '... Still, in thinking about what draws faculty to research, two factors I take to be of uppermost importance. First comes love of learning. That may sound trite, sentimental, and self-serving, but nevertheless it is true. Career choices are affected by the requirements "of the trade." Those who opt for the military must have a certain predisposition toward uniforms, demanding physical challenges, and patriotism. Politicians have to feel some attraction toward people, power, and oral communication. And academics are students who never grow up-people who wish to remain students for the rest of their lives. Is this not one way to express a love of learning? ...', and in p.165: '... We professors have the income of civil servants but the freedom of artists. This imposes certain obligations. The formal duties imposed by our institutions are minimal, anywhere between six and twelve hours in the classroom per week during eight months of the year. Yet most of us work long hours and spend many evenings at our desks or in our laboratories. We do not tell students that this is our day off, that they must seek someone else with whom to discuss their problems. We do practice our profession as a calling, considering ourselves not employees but shareholders of the university: a group of owners. "Share values" are determined by the quality of management and the product. We seek to keep those values as high as possible...'.

I should also mention Clark Kerr. He wrote a very often quoted paragraph concerning the solid stability of universities: '.... Heraclitus said that "nothing endures but change." About the university it might be said, instead, that "everything else changes, but the university mostly endures" - particularly in the United States. About eighty-five institutions in the Western world established by 1520 still exist in recognizable forms, with similar functions and with unbroken histories, including the Catholic church, the Parliaments of the Isle of Man, of Iceland, and of Great Britain, several Swiss cantons, and seventy universities. Kings that rule, feudal lords with vassals, and guilds with monopolies are all gone'.

These seventy universities, however, are still in the same locations with some of the same buildings, with professors and students doing much the same things, and with governance 
carried on in much the same ways. There have been many intervening variations on the ancient themes, it is true, but the eternal themes of teaching, scholarship, and service, in one combination or another, continue. Looked at from within, universities have changed enormously in the emphases on their several functions and in their guiding spirits, but looked at from without and comparatively, they are among the least changed of institutions ...' (Kerr 2001).

The above statement is tested by the current pandemic and consequent adaptations of the universities, to be discussed later. But to my mind its wisdom is left unscathed by the passing tempest!

I was educated in the belief of the importance of education for all: for each individual but also for mankind since highly educated people create synergies and carry out interactions that move society forward. As an engineer, I was trained to seek clarity, planning and organization, and Kerr's California Master Plan for Higher Education seemed to me an example of a good well designed policy:

- postsecondary education should be available to all,

- academic progress should depend on the student performance only, and

- a public offer organized in three systems each one concentrating on types of needs, thus avoiding wasteful allocation of public resources duplicating efforts.

He preconized that public offer of higher education in California should include diverse types of institutions: (i) state institutions strongly oriented to research - the University of California (UC) system; or (ii) mainly oriented towards teaching as the California State University (CSU) system; and finally, (iii) catering for students seeking a shorter postsecondary, more practical education, in the now called community colleges (this public offer should coexist, of course, with private institutions - strongly research based as CalTech or Stanford, or otherwise as Pepperdine, Chapman, etc.).

All Californian graduating high school seniors should have a place in the state system: the top $12.5 \%$ would be candidates to a tuition-free place at a campus of the University of California; the top 33.3\% would be able to enter the California State University system. Junior colleges (now 'community colleges') would accept any students capable of benefiting from instruction. Graduates of the junior colleges would be guaranteed the right to transfer to the UC or CSU systems in order to complete bachelor's degrees. The research based UC would award PhD degree, whereas the CSU system, further to awarding master's degrees, would award joint doctorates with the UC. The availability of such public offer would not preclude private organizations where a diversity of funding sources (US research funds, and/or tuition fees, etc.) are found, and cater for the needs of specific groups or types of students, as those based on religion, wealth or others.

Clark Kerr was a remarkable individual with a keen sense of humor, who synthetized the requirements put upon the university rector (president or equivalent) as follows: '... The university president in the US is expected to be:

- a friend of the students,

- a colleague of the faculty,

- a good fellow with the alumni,

- a sound administrator with the trustees,

- a good speaker with the public,

- an astute bargainer with the foundations and the federal agencies,

- a politician with the state legislature, 
- a friend of industry, labor, and agriculture,

- a persuasive diplomat with the donors,

- a champion of education generally,

- a supporter of the professions (particularly law and medicine),

- a spokesman to the press,

- a scholar in his own right,

- a public servant at the state and national levels,

- a devotee of opera and football equally,

- a decent human being,

- a good husband and father,

- an active member of a church.

Above all he must enjoy traveling in airplanes, eating his meals in public, and attending public ceremonies. No one can be all of these things. Some succeed at being none! (Kerr 2001, 22).

Above, Kerr refers to the rector or president of the university. For full professors, excellence in research is an added requirement, and not much of the above list is dropped - illustrating how tough the professors' job can be. The risk of inadequate time management is a serious concern for the academic staff, suggesting the need for some planning.

So that navigation is not just near-shore, individuals and institutions need planning. Strategic planning may be a tool of interest at institutional level, but also to help individual staff members in moving their career forward. Of course planning - formal strategic planning, or other - has been in place at FEUP for some time, as promoted by Deans as Marques dos Santos et al. The last planning exercise was mainly due to the leadership of my colleague A. Torres Marques, consisting of a process with strong involvement of FEUP whose outcomes already include a valuable book by J. Félix Ribeiro: 'Economia Tecnologias e Engenharia: Contributo para uma Reflexão Estratégica da FEUP com o Horizonte 2037' (Ribeiro 2020).

In 1992 I attended the College Management Program of Carnegie Mellon University taught, among others, by one of the pioneers of academic strategic planning, George Keller. In 'Academic Strategy: the Management Revolution in American Higher Education' Keller (1983) synthetizes the institutional strategic planning starting by what it is not, '...

- it is not the production of a blueprint;

- it is not a set of platitudes;

- it is not the personal vision of the president or board of trustees;

- it is not a collection of departmental plans, compiled and edited;

- strategic decision making is not done by planners;

- it is not a substitution of numbers for important intangibles;

- it is not a form of surrender to market conditions and trends;

- strategic planning is not something done on an annual retreat;

- it is not a way of eliminating risks;

- it is not an attempt to read tea leaves and outwit the future ...'

Instead, it is:

- '... academic strategic decision making means that a college, school, or university and its leaders are active rather than passive about their position in history;

- strategic planning looks outward and is focused on keeping the institution in step with the changing environment; 
- academic strategic making is competitive, recognizing that higher education is subject to economic market conditions and to increasingly strong competition;

- strategic planning concentrates on decisions, not on documented plans, analyses, forecasts, and goals;

- strategic making is a blend of rational and economic analysis, political maneuvering, and psychological interplay;

- strategic planning concentrates on the fate of the institution above anything else ...'.

In his essay on Keller's book, Temple (2018) notes this was one of the first works to suggest strategic approaches in the management of HE institutions, but adds that the limitations of Keller's approach to strategy became apparent with time, since 'the unknowns, not to mention the unknowables, make the formulation of strategy more like writing imaginative fiction than the tough-minded quantitative discipline its adherents claim it to be'. A criticism of the import, rise and fall of management fads into university administration is Robert Birnbaum's book 'Management Fads in Higher Education' noting that 'The fundamental fallacy of strategic planning, in business or education, was the implicit assumption that the analytic processes of planning can lead to the synthesizing process of strategy' (Birnbaum 2000, 73-74). Whatever the controversy, truth is that forward looking and planning are requirements to guide progress.

Some people, especially top achievers and doers, show no interest for the past and perhaps even contempt for archivists. António Guterres, distinguished IST alumnus and current UN Secretary-General, said 'I will never write my memoirs, I do not take notes of anything that goes on, I do not have a diary and I discarded all the papers. What has an advantage, every day is always forward thinking, not backward (Latoeiro and Domingues 2021). But nature is diverse: I do keep papers and vestiges, and that is a problem in these times of space constraints! (I have permanently lost information kept in diskettes since they became unreadable just being stored; by contrast, papyri of Ancient Egypt, even some burned in the eruption of Mount Vesuvius of 79 AD, keep some legibility ...).

\section{Ethics. Role models}

Using the handy National Society of Professional Engineers definition, 'Science is knowledge based on observed facts and tested truths arranged in an orderly system that can be validated and communicated to other people. Engineering is the creative application of scientific principles used to plan, build, direct, guide, manage, or work on systems to maintain and improve our daily lives' (NSPE, n.d.). Discussing similarities and differences between engineers and scientists, Professor Henry Petroski notes that there are no borders but a continuum between science and engineering (Petroski 2010), reckoning that engineers and scientists move freely back and forth along the continuum (Liang and Yeh 2014).

Professionals may be characterized by fulltime work, commitment to work as a calling, having prolonged training, service orientation, and autonomy in applying professional judgment to clients' problems (Simpson 1972). Frequently engineers are salaried employees of companies, and organizations and engineers present strong interdependency (Plovnick 1972). Professional values - specialized competence, autonomy, commitment to career, and influence and responsibility in the use of special competence - may conflict with aspects of the organizational context as goals, controls, incentives, and influence. A consequence of the interdependency is the growing importance of professional standards within organizations, while the professions are increasingly subjected to bureaucratic controls (Kaplan 1963). The tensions are sharply described by Merton (1947, 1968): '... Deriving in part from the 
specialization of functions, engineers, not unlike scientists, come to be indoctrinated with an ethical sense of limited responsibilities. The scientist, busy on his distinctive task of carving out new knowledge from the realm of ignorance, has long disclaimed responsibility for attending to the ways in which this knowledge was applied. (History creates its own symbols. It required an atomic bomb to shake many scientists loose from this tenaciously held doctrine).

So, in many quarters, it has been held absurd that the engineer should be thought accountable for the social and psychological effects of technology, since it is perfectly clear that these do not come within his special province. After all, it is the engineer's "job" - note how effectively this defines the limits of one's role and, thereby, one's social responsibility - to improve processes of production, and it is "not his concern" to consider their ramified social effects. The occupational code focuses the attention of engineers upon the first links in the chain of consequences of technological innovation and diverts their attention, both as specialists and as citizens, from succeeding links in the chain as, for example, the consequencesfor wage levels and employment opportunities'.

As observed by Butler (1963), '... The professional in industry rarely enjoys the same ready acquiescence to his recommendations as does the doctor or lawyer, whose patients and clients are prone to respect the authority of those they consult. "Since the research scientist does not take the major risks, he does not acquire the right to the last word. "...'.

Long ago, I recognized the relevance of an ethics content in engineering education. Rui Guimarães, a distinguished FEUP Professor, and my predecessor in teaching Design of Machine Elements, used to say that ethics education of university students is not achieved through lectures but instead is a result of their immersion in an ecosystem that adopts high ethical standards and imposes them to staff and students. I recognized truth in this opinion, but nevertheless thought - like many others as Didier (2000), Hamad et al. (2013), etc. - that ethical situations that may occur in engineering practice should be specifically discussed, even in course or related work (de Castro 1999). The role of professional associations in establishing ethical codes is essential. In 1998-2002 I was a member of the ASME Board on Professional Practice and Ethics (BPPE). Later I joined my own university Ethics Committee, which I left when I realized that most of the time and effort concentrated on ethics in life sciences, certainly a necessary endeavor but peripheral to my ethical interests. My interests are more on the ambiguities of certain engineering situations, conflicts of interest, safeguards of engineers and whistleblowing, and less on ethical aspects of clinical trials as confidentiality, consent etc. The UP Ethics Committee site hosts my 1996 paper (in Portuguese) 'Ensinar Engenharia: Profissão e Ética' (Teaching Engineering: Profession and Ethics) (de Castro 1996). The Richard Felder's Legacy Website (NC State University and College of Engineering, n.d.) states that '... college teaching may be the only skilled profession for which no preparation or training is provided or required. You get a Ph.D., join a faculty, they show you your office, and then tell you "By the way, you're teaching [course] 205 next semester. See you later." The result is the consistent use of teaching techniques that have repeatedly been shown to be ineffective at promoting learning.

Many professors are surprised to learn that...

- There are well-defined instructional techniques that make teaching more effective.

- These techniques can be introduced slowly and methodically, without compromising coverage of the syllabus. They do not require large expenditures of money, time and effort. 
- Most importantly, the techniques have been validated by careful, documented, repeatable research. Their effectiveness is not simply a matter of opinion. They work!

In 'Teaching Engineering' Wankat and Oreovicz (1993) mention Cannon 2 of ABET .... engineers shall perform services only in the areas of their competence .... ${ }^{3}$. As a result of the above, absence of specific pedagogical training and knowledge may be seen as an ethical violation engineers would be providing services which include at least one dimension that is outside the scope of their competences! This 'violation' may be a surprise for many, but awareness of this situation should contribute to emphasize the need for looking seriously at pedagogical aspects. At FEUP mention may be made of efforts of the 'Laboratório de Ensino e Aprendizagem / Teaching and Learning Lab', led by João Pedro Pêgo since $2019^{4}$.

Again from Wankat and Oreovicz (1993), teaching staff should...

'1 Guide the learner. Be sure that students know the objectives. Tell them what will be next. Provide organization and structure appropriate for their developmental level.

2 Develop a structured hierarchy of content. Some organization in the material should be clear, but there should be opportunities for the student to do some structuring. Content needs to include concepts, applications and problem solving.

3 Use images and visual learning. Most people prefer visual learning and have better retention when this mode is used. Encourage students to generate their own visual learning aids.

4 Ensure that the student is active. Students must actively grapple with the material. This can be done internally or externally by writing or speaking.

5 Require practice. Learning complex concepts, tasks, or problem solving requires a chance to practice in a nonthreatening environment. Some repetition is required to become both quick and accurate at tasks.

6 Provide feedback. Feedback should be prompt and, if at all possible, positive. Reward works much better than punishment. Students need a second chance to practice after feedback in order to benefit fully from it.

7 Have positive expectations of students. Positive expectations by the professor and respect from the professor are highly motivating. Low expectations and disrespect are demotivating. This is a very important principle, but it cannot be learned as a "method." A master teacher truly believes that her or his students are capable of great things.

8 Provide meansfor students to be challenged yet successful. Be sure students have the proper background. Provide sufficient time and tasks that everyone can do successfully but be sure that there is a challenge for everyone. Success is very motivating.

9 Individualize the teaching style. Use a variety of teaching styles and learning exercisesso that each student can use his or her favorite style and so that each student becomes more proficient at all styles.

10 Make the class more cooperative. Use cooperative group exercises. Stop grading on a curve and either use mastery learning or grade against an absolute standard".

The above bullet list represents and celebrates good common sense; many other 'good practice' lists are found. Academic staff should feel the need for some structured thought on the learning and teaching processes. FEUP has been active for many years in these matters, even if pedagogical issues were the object of occasional and not very structured efforts. As an

\footnotetext{
${ }^{3}$ ABET no longer includes such list (Cannons) in its docs., but mention of ethics is pervasive in their site.

4 https://paginas.fe.up.pt/ lea/. LEA was created at FEUP by J. Martins Ferreira in 2008, and led by Paulo Garcia in 20132018.
} 
example of such efforts, I mention the course 'Ensinar Engenharia; Princípios Básicos' (Teaching Engineering: Basic Principles), which took place at FEUP in $1999^{5}$, taught by several professors but also by a psychologist, Diana da Silva Dias, that launched in 1995 the Gabinete de Psicologia da FEUP. This just illustrates that a useful discussion on teaching engineering needs diversified viewpoints and perspectives.

Evolution of the consideration of ethics in the profession is discussed by Mitcham (2009), including teaching of ethics, and even ethical obligations for authors, reviewers, and conference organizers. The site of the ASME keeps update info (ASME, n.d.).

Engineering takes place within society. When I started my Applied Mechanics MSc studies at Imperial College I came across the seminal book by E. F. Schumacher 'Small is Beautiful' (Schumacher 1975). The provocative subtitle was what attracted me first: 'a study of economics as if people mattered'. This book was one the sources of the so-called 'intermediate technology' movement, with environmental and development concerns and emphasis in field work particularly in the $3^{\text {rd }}$ world; it also generated substantial literature available, among libraries and other locations, in the no longer existing Intermediate Technology bookshop in the very cool Bloomsbury neighborhood of London.

Accompanying increasing environmental and development concerns everywhere, the movement evolved and is now known as 'appropriate technology'. In their recent paper on design methodology, Sianipar et al. (2013) celebrate the original concepts with the chosen paper subtitle: ... engineering as if people mattered. There are already historical exams of the impact of the movement, as in Willoughby (1990). The evolution of the movement towards mainstream is suggested by initiatives like Engineering for Change (E4C, n.d.), bringing together major engineering professional societies as ASME, IEEE, academe as MIT and IIT Madras, and companies such as Siemens. 'E4C's mission is to prepare, educate and activate the international engineering workforce to improve the quality of life of underserved communities around the world. We do this by providing resources and platforms that accelerate the development of impactful solutions and ensure public health and safety around the globe' (E4C, n.d.).

An increasing number of initiatives seek to bring engineering and engineering education to the solution of the problems of humankind - the United Nation's 17 Sustainable Development Goals (SDGs) ${ }^{6}$ are examples of challenges facing our planet, and can be used as a way to focus our attention and energy on specific problems.

Addressing the SDGs is critical to maintaining peace and prosperity, and it is something we, as technical professionals, can help achieve. We are in a unique position to design the world how we would like to see it - more purposeful, sustainable, and accessible to all 7 .

Even peace became a matter for engineering education ${ }^{8}$ : at Drexel Univ. (Philadelphia) the 48 credit MS Degree in Peace Engineering is open to students from STEM backgrounds and combines case-based courses with experiential learning internships and research development efforts that are driven by the needs of the peacebuilding community. Students will engage in

\footnotetext{
5 Módulo 3: Promover a motivação, as competências pessoais e os conceitos; teachers: Ca rl os Costa, Adélio Mendes, Diana Dias, Paulo Tavares de Castro, FEUP, 7-14 Jan. 1999. This course included attention to: G. Brown and M. Pendlebury, 'Assessing Active Learning', CVCP Universities' Staff Development and Training Unit. 1992; and 'Effective learning and te a ching in higher education', CVCP Universities' Staff Development and Tra ining Unit, 1992.

6 https://sdgs.un.org/goals

7 Milligan, M. 2018. “Engi neering a Better Future”. https://www.abet.org/engineering-a-better-future/.

8 https://drexel.edu/engineering/academics/areas-of-study-programs/peace-engineering/masters-program/
} 
online and face-to-face courses to develop advanced skills, understand the human dimensions of conflict, and develop a toolbox of transferable skills such as negotiation and project management. These skills will enable graduates from the program to succeed in peacebuilding and as leaders in STEM professions.

Technical Focus Areas:

Students will have the opportunity to participate in technical focus sequences in order to focus their peace engineering skills in some of the following areas: Systems Analysis, Software Development, Machine Learning and Al, Information Security, Database Management, Information Retrieval, Data Mining, Web and Mobile Development, Game Design, Serious Gaming, Interactivity, Water, Sanitation, and Hygiene (WASH), Power Systems and Distribution.

Future observers of the present world will see a bellicose, tribal and divided humankind, lacking worldwide institutions/government that would make it possible sustainable development for all (as different from unsustainable development for just a few) ...

The above paragraphs could project a rather erroneous impression that my free time at Imperial and later Cranfield was concerned with sustainable development, ethics and related matters. Those were interests, among many others - including motor racing. I mention this en passant, to give me the opportunity to celebrate here Ingegnere Mauro Forghiere, Figure 3, the engineering wizard behind the Ferrari successes in the seventies. Unlike the XIX century with popular engineering heroes like Gustave Eiffel ${ }^{9}$, George and Robert Stephenson and the like, the evolving characteristics of my profession - mechanical engineering - do not favor transformation of mechanical engineers in popular stars, as for example happens in architecture. Nevertheless, as elsewhere, Mechanical Engineering also benefits from wellknown role models, and in those years, Forghieri was certainly a powerful one for many Mechanical Engineering students!

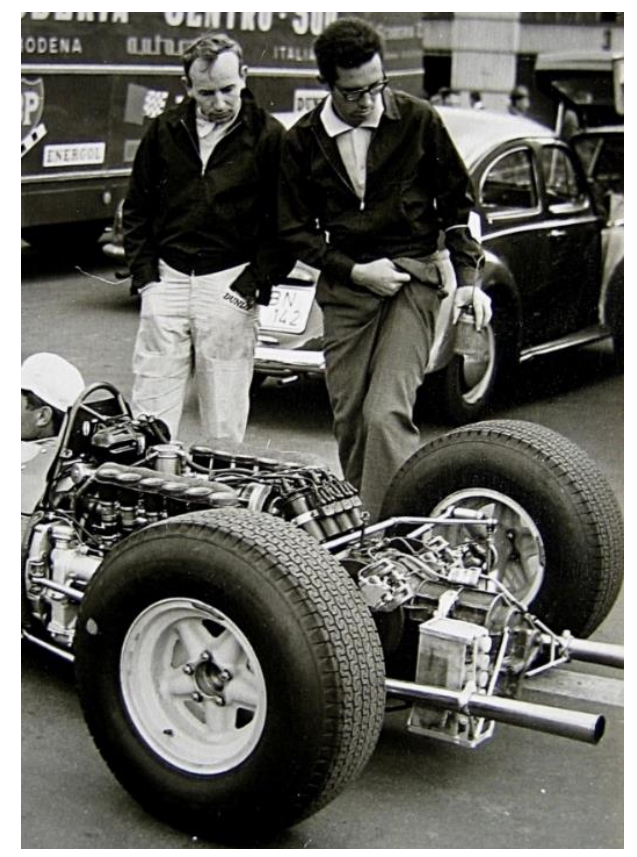

Figure 3: 1965 photo of Ingegnere Mauro Forghiere (right) and F1 World Champion John Surtees (left) looking at a V12 engine ${ }^{10}$

\footnotetext{
${ }^{9}$ Eiffel was an alumnus of École Centrale des Arts et Manufactures. Contrary to popular misconception, he chose to specialize in che mistry. Nevertheless, his structural designs were and a re superb!

10 Wiki pedia, s.v., "Ma uro Forghieri”, last modified January 9, 2021, 18:18, https://en.wikipedia.org/wiki/Mauro_Forghieri.
} 
I finish this section still in these matters of image projected by the profession, quoting again the wisdom of Professor Henry Petroski: '... It is an old joke among engineers that when newspapers report some positive technological achievement - like a successful rocket launching or the safe landing of an interplanetary probe - it is attributed to scientists. When something negative happens - like a rocket exploding on the launch pad or a probe going astray or otherwise malfunctioning - it is the engineers who are blamed ...' (Petroski 2010).

\section{Campus}

According to Oakeshott (2004) '... A university is not a machine for achieving a particular purpose or producing a particular result; it is a manner of human activity ...' and '... What distinguishes a university is a special manner of engaging in the pursuit of learning. It is a corporate body of scholars, each devoted to a particular branch of learning: what is characteristic is the pursuit of learning as a co-operative enterprise. The members of this corporation [...] live in permanent proximity to one another. And consequently we should neglect part of the character of a university if we omitted to think of it as a place. A university, moreover, is a home of learning, a place where a tradition of learning is preserved and extended, and where the necessary apparatus for the pursuit of learning has been gathered together...'; and, as underlined by Mónica (2013), Oakeshott continues: '... The pursuit of learning is not a race in which the competitors jockey for the best place, it is not even an argument or a symposium; it is a conversation'.

In a discussion of Oakeshott's writings, Williams (1989) notes that '... at university a person does not become educated simply through study alone. A university offers a full educational experience, not just through its curriculum of studies and programme of extracurricular activities, but also through its genius loci and through the opportunity it offers to be part of a human community'.

Distance education is an old interest of mine. Already in 1974 I was subscriber of the journal 'Education at a Distance' launched that same year. It was published by the Open University (OU), created five years before (in 1969) (Grugeon and Tibbenham 1980). Open (in Open University) has, of course, a social implication of openness, namely inclusiveness of the admissions regulations ${ }^{11}$. Figure 4 shows the cover and contents page of issue 1,1974 . In the contents of that inaugural issue, the article 'Teaching by telephone: the problem of teaching without the visual channel' looks particularly dated (considering what a telephone was back then!). But other title in the same issue, 'Social equality as an Open University objective', sounds still relevant and timeless.

\footnotetext{
11 From the Open University site, accessed April 20, 2021: '... Admissions: For most undergraduate degrees, you don't need any formal qualifications, or to pass an entry test, to study with us. For postgraduate degrees, you will normally be required to hold a degree equivalent to a UK bachelors degree. For all levels of study with The Open University, you will need the following: - Proficiency in the English language. Please see English skills. - Access to a computer with broadband internet access, which will be vital for online learning ...'

http://www.openunive rsity.e du/study/admissions-applications?gclid=EAlalQobChMI7pyC4c-

N8AIVfQMGAB3T0QnwEAAYASABEgKPKPD_BwE\&gclsrc=aw.ds
} 

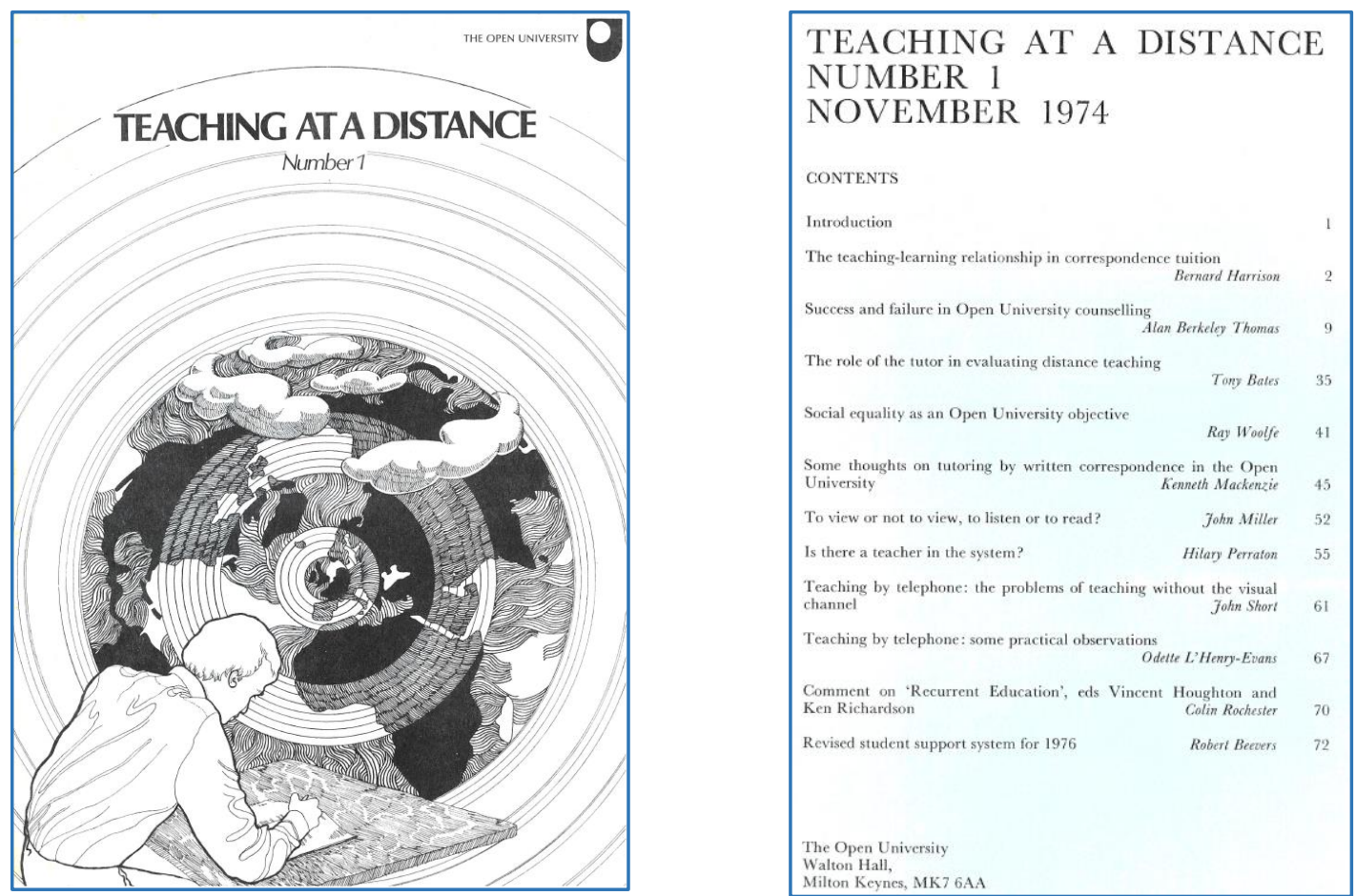

Figure 4: The firstissue of the Open University journal Teaching at a Distance (Nov. 1974)

The Open University (OU) publishes a vast amount of textbooks and other materials in support of its activities. Occasionally in my own courses at UP I used OU texts, namely the course 'Materials under stress - T351' (Reid et al. 1978) of which Professor Nick Reid was chair, and where case studies are presented and discussed with great pedagogical skill.

Whereas traditional, presential undergraduate education takes place in a campus, and mainly involves students from late teens to early twenties following programs with substantially fixed calendars, distance education typically involves education of adults, in continuing, self-paced and self-managed education and independent study. Distance education favours flexibility. And, as noted by Rocha Trindade, a leader of the distance education in Portugal, in a presentation for EADTU (European Association of Distance Teaching Universities), 'higher education institutions in the Anglo-Saxon culture tend to be more flexible than those of Latin or German influence. In the former undergraduates as well as graduate programmes offer wide possibilities of choice to students from a "menu" of relevant subjects, whereas in the latter variations in curriculum are only allowed in a small number of optional courses' (Trindade 2005).

Some early institutions for post-secondary education at a distance are listed in Table 1. 
Table 1: Universities for teaching/learning at a distance

(source: Valcke and Thorpe 1995)

\begin{tabular}{|l|l|c|}
\hline \multicolumn{1}{|c|}{ Country } & \multicolumn{1}{|c|}{ Institution } & $\begin{array}{c}\text { Year of } \\
\text { Foundation }\end{array}$ \\
\hline Malaysia & Universiti Sains Malaysia & 1969 \\
\hline U.K. & The Open University & 1969 \\
\hline U.S.A. & Empire State College(State University New York) & 1971 \\
\hline Spain & Universidad Nacional de Educacion a Distancia & 1972 \\
\hline Pakistan & Allama Iqbal Open university & 1974 \\
\hline Germany & Fernuniversität & 1975 \\
\hline Australia & Deakin University & 1975 \\
\hline Thailand & Sukhothai Thammathirat Open university & 1978 \\
\hline Canada & Open Learning Institute & 1978 \\
\hline Portugal & Instituto Português de Ensino à Distância (Grave-Resendes and Nunes 1998) & 1980 \\
\hline Denmark & Jysk Aabent Universiteit & 1982 \\
\hline Indonesia & Open university & 1984 \\
\hline Italy & Consorzio per I'Università a Distanza & 1984 \\
\hline Japan & University of the Air, now the Open University of Japan & 1984 \\
\hline Netherlands & Open universiteit & 1984 \\
\hline Portugal & Universidade Aberta & 1988 \\
\hline
\end{tabular}

The early Portuguese interest in this field noted in Table 1 makes more intriguing that the Universidade Aberta was not called for a major role in the COVID crisis, where many teachers as myself were converted into distance teachers via a ten-minutes introduction to booking of ZOOM meetings.

The current COVID crisis imposed radical sudden transformation of university life, with the generalization of ZOOM-assisted teaching. The cover of the August 8-15 2020 issue of The Economist, Figure 5, is a powerful suggestion of the loss created in the institutions and more importantly in the students.

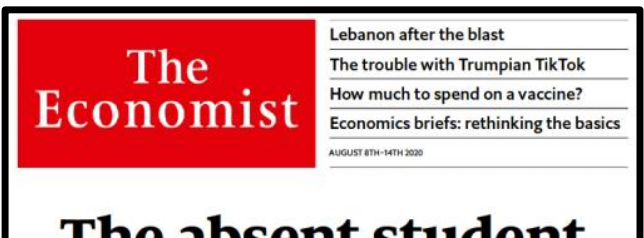

\section{The absent student}

How covid-19 will change college

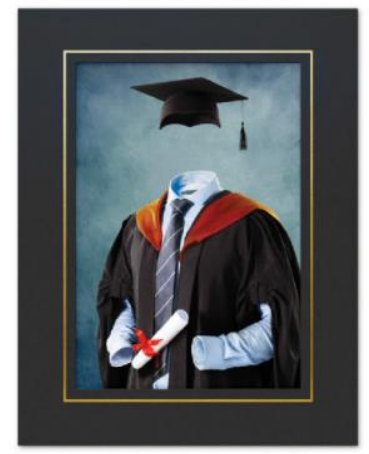

Figure 5: Cover of the August 8-15 2020 issue of The Economist

The provision of hard- and software to allow full benefit from online distance education is a social concern (namely for the appropriate technology movement). The use of ZOOM and similartools was justified on the grounds of the widespread availability of technical conditions. For example in Portugal, pc's are certainly widespread but social conditions as housing are 
certainly not uniform - unfortunately inequality in Portugal is notorious ${ }^{12}$. If some students certainly had their own room or office to follow online activities in complete concentration, others had to share their pc's with younger brothers and sisters, in rooms simultaneously used for many other activities, which suggests the inefficiency of the process. And although Universidade Aberta had a deep knowledge of distance teaching (as mentioned before), surprisingly UA was not involved at all or even mentioned in the hastily made arrangements in many institutions to face the confinement.

COVID also implanted within the universities notions as testing and exams under proctoring surveillance (Flaherty 2020) with techniques as eye tracking among others, in a dystopian world reminding Orwell's 'Nineteen Eighty-Four' (Orwell 1949). Compulsory retirement because of 70 years age limit in my case had at least the beneficial aspect that I will certainly not be involved in those operations!

The pandemic has already generated substantial literature related to academe; and as alluded above assessment is certainly a key issue. This is dealt with e.g. by Gibbs (2020), mentioning that, apparently, contract cheating offers are widespread. This evokes the need for a stronger ethical basis in academe, but that depends also of the prevalent ethical mood in society. Gibbs lists the QAA features of effective assessment (QAA 2018) as follows:

- it is aligned to learning outcomes and teaching activities;

- is reliable, consistent, fair and valid;

- holistic;

- inclusive and equitable;

- explicit and transparent;

- purposeful and supports the learning process;

- timely;

- efficient and manageable;

- supportive, and

- encourages academic integrity.

How to translate these aspirational statements into practice, in COVID times, is a challenge; I only can offer my personal experience, of using an improvised continuous assessment system, based upon assignments and tasks from time to time given to students. This increased substantially the amount of my time dedicated to teaching, house confinement involving permanent email dialogue with most of the students. The experience was exhausting for me but apparently useful for students, as witnessed by an unsolicited remark I received just after delivering my course: '... I really hope I did a good job throughout the semester and responded. At least I finish this course with a clear head because I know I did my best. Once again teacher ... Thank you for everything and thank you for helping me to grow as a student and professional with everything I learned from you, from classes to the tips you gave me at work. ... email June

\footnotetext{
12 The Gini coefficient is a representation of the income or wealth inequality within a nation. A Gini coefficient of zero corres ponds to perfect equality, whereas a Gini coefficient of one (or 100\%) indicates maximal inequality. Situation in Portugal, as compared with other EU member countries, is presented e.g. in: Carlos Farinha Rodrigues (coord.), Rita Figueiras, Vítor Junqueira, 'Desigualdade do Ren dimento e Pobreza em Portugal: As consequências sociais do programa de ajustamento', Fundação Francisco Manuel dos Santos, Setembro de 2016 (see in particular pp.42-43). https://www.ffms.pt/FileD ownload/dd40884a-16bd-4709-b488-da838f8972b5/desigualdade-do-rendimento-e-pobrezaem-portugal.

Summary of the above study is: Ca rlos Farinha Rodrigues (coord.), Rita Figueiras, Vítor Junqueira,' Introdução ao estudo Desigualdade do Rendimento e Pobreza em Portugal', Fundação Francisco Manuel dos Santos, Agosto de 2016.https://www.ffms.pt/FileDownload/79783fb3-9b9f-4ba1-9ee4-473b82834d 0c/introducao-ao-estu do-desi gual da dedo-rendimento-e-pobreza-em-portugal.
} 
23, 2020 ...'. Of course my chosen method was only compatible with the limited number of students that attended my courses in COVID times. With larger numbers, I should be obliged to adopt something else...

This leads me to some reflections about number of students in HE. I already mentioned my admiration for the wisdom of Clark Kerr in ensuring a HE opportunity for all capable Californians. Likewise, another reading that influenced me was the UK Robbins report (Committee on Higher Education 1963). The issue of HE for all capable of benefiting from it is vividly stated in the passage '... The numbers who are capable of benefiting from higher education are a function not only of heredity but also of a host of other influences varying with standards of educational provision, family incomes and attitudes and the education received by previous generations. If there is to be talk of a pool of ability, it must be of a pool which surpasses the widow's cruse in the Old Testament, in that when more is taken for higher education in one generation more will tend to be available in the next ...' (Committee on Higher Education 1963, chap. VI, §146, 54).

All this illustrates the tension created by numbers. Ça va sans dire that I favor teaching as a dialogue tête-à-tête between human beings, as it was in the old tutorial system, where students receive direct feedback on their periodic essays or work in a small discussion setting. This is not compatible with large numbers; but tools are being considered for dealing with large numbers, as MOOCs where computers are programmed using Al to simulate the feedback offered by human readers. As stated by Reilly et al. (2014) '... Currently most assessment in MOOCs is based on computer-scored multiple choice questions, formulaic problems with correct answers, logical proofs, computer code, and matching items, often with targeted feedback based on the responses given [...]. While this type of assessment works well in certain disciplines, others rely more on open-ended writing assessments for students to fully demonstrate their learning. Many MOOC environments provide tools for delivering openended writing assignments and either self-or peer-scoring with a rubric, but the quality of the scoring and feedback can vary greatly, possibly making it inappropriate for high-stakes assessment ...'. This situation may, meanwhile, have improved.

In 'Invasion of the MOOCs', Krause and Lowe (2014) recall, from the online petition 'Professionals Against Machine Scoring of Student Essays in High-Stakes Assessment' (Human Readers 2013) '.... computerized essay rating is:

- trivial, rating essays only on surface features such as word size, topic vocabulary, and essay length;

- reductive, handling extended prose written only at a grade-school level;

- inaccurate, missing much error in student writing and finding much error where it does not exist;

- undiagnostic, correlating hardly at all with subsequent writing performance;

- unfair, discriminating against minority groups and second-language writers;

- secretive, with testing companies blocking independent research into their products.

This is no small criticism, and although I searched, I could not find contradictory to the above assertions.

Some perceive the pressure upon academic staff as increasing every day. This goes in tune with the progressive substitution of tenured faculty, particularly in the USA, for comparatively inexpensive untenured or adjunct staff. Inexpensive distance ZOOM teaching, Al-based solutions to deal with large number of students, and the like, implemented during the COVID 
crisis, may bring to HE administrators and bean counters the idea of transforming the crisis response into a new normal.

As observed by Archibald and Feldman (2010) '... If a physician's patients are given cursory examinations or are shunted off to nurses, costs will not rise as fast ...'. Universities administration are well aware that economies may be made through productivity increases e.g., teaching larger numbers with less staff, or hiring cheaper staff as 'adjunct' in the US, 'convidados' in Portugal, etc. As noted in a National Academies Press book (National Academy of Sciences, National Academy of Engineering, and Institute of Medicine 2014), discussed in the frame of the 2037 strategic plan of FEUP (Carvalho et al. 2015), in the USA there is an '... increase in the use of contingent or adjunct faculty, who cost less than tenure-track professors and do not require the start-up packages and lifelong job commitment that tenured faculty receive ...'. We might add that the increase in non-tenured faculty, further to economies, may disrupt the traditional independence of academic staff, since non tenured faculty are exposed to the whims of the administration.

As Ramos (2020) points out, (in a loose translation of the Portuguese original) '... To describe in a few words the crisis that universities are in today is to note that, from elitist corporations, they have become mass certifying companies, which disqualify the precarious university workers in favor of the interests of university business management. There was talk of "elearning" and "distance learning" long before the epiphany that the coronavirus is causing in rectoral chambers and university governing boards, but there is an imminent risk that the provisional will become definitive, and that what is advocated as a remedy will become the door to be opened for a radical transformation of the university education system.

Managers have long been questioning the economic rationality of maintaining a hired faculty that creates constant problems in the finances of institutions. But there is nothing as a good "outbreak narrative" to bring about the obvious solution: the university without professors. ....' To keep up with the new teaching gadgets and techno-fads may be a time consuming endeavour. Mintz (2017) is however optimistic: whilst many innovations 'consists of little more than skills and drills or edu-tainment', technology should be used to 'promote inquiry, enhance collaboration, offer case-based or challenge-based learning experiences, and, above all, to give students opportunities to create ...'. Reference to the EU plan for the promotion of digital education should be mentioned in this context (EC 2020, 2021).

As Mintz (2017) describes, '... Pedagogy, delivery modes, instructional staffing, and assessments are all being rethought - driven in part by advances in the learning sciences, cost pressures, and a new generation of students with distinct interests and needs. I suspect that the faculty role will shift further in the years ahead to meet this new reality, with an increasing emphasis on the faculty member as learning architect - a designer of learning experiences, a mentor, and overseer of independent research, internships, study abroad, and other forms of experiential learning ...'.

Anyway, a positive sign seems to be an increasing awareness of the need for quality teaching, where in many universities staff are only rewarded for excellence in research. An example of this trend is the Teaching Excellence Framework (England) which aims at evaluating (and therefore improving) the quality of teaching. As Hall (2017) explains in The Guardian, there are persuasive incentives for universities to get a good teaching assessment: the old stick and carrot game, or translating, less or more funding. The question is how does the government arrives to a gold, silver and bronze rating; a selection of metrics together with written submission by the universities will be evaluated by experts, taking into account the types of 
students of each particular institution. The scheme was thoroughly reviewed by an expert panel (Pearce 2019). This goes back to the well accepted notion that quality in HE is the delta $x$ of knowledge, abilities and maturity of each student, not the absolute value of achievement which of course is strongly dependent upon the conditions at entry.

\section{Activities}

According to conventional wisdom, a professor is expected to generate significant research contributions, to teach, to contribute to the management of his institution, and to build bridges between his institution and society at large.

There are many nuances of this general formula: namely in what concerns the relative importance of each type of contribution along the career path. This is alluded e.g. in Frølich et al. (2018), where it is clear that in some countries a specialization in teaching or in research may exist, particularly according to the type of HE institution involved.

And in research itself, several postures may be found. Due to its uncommon blunt and frankness, I quote ipsis verbis the 2004 ASME Timoshenko Medal acceptance speech by the mechanical engineer turned mathematical physicist Professor Morton E. Gurtin: '... I'm a lucky person; I can't believe I get paid to do what I do. It's difficult to describe to a lay person that wonderful, almost magical moment of revelation in the solution of a problem or in the understanding of a concept. The problem or concept need not be grandiose, or even important, and often it is forgotten the next day. But that seems unimportant. [...] Good theoretical science is done by a few dedicated people working alone or with one or two colleagues; this science does not need the large grants that have made prostitutes of most of us, including me. The need to be relevant, the need to be applicable to industry; these are not forces that lead to advances; what leads to advances, often spectacular, is simply the curiosity of the individual scientist, just as Einstein's curiosity about the structure of space-time led to the theory of relativity. Big science is a driving force for mediocrity ...' (Gurtin 2004).

A groundbreaking publication on the many roles of university academic staff is the $E$. L. Boyer book 'Scholarship reconsidered' (Boyer 1990). Boyer reminds that in 1869 the Harvard College president stated that "the prime business of American professors ... must be regular and assiduous class teaching". In the USA, the Land Grant College Act (Morrill Act of 1862) framed the reshaping of the mission of $\mathrm{HE}$, to include the 'agricultural and mechanical' needs of society. This enlarged the scope of $\mathrm{HE}$, from the original civic and religious leadership intended at Harvard, to include more mundane and practical concerns. At the close of the nineteenth century, the influence of the German university and its research orientation started to influence HE education in the USA. The University of Chicago, founded in 1890, required 'each appointee to sign an agreement that his promotions in rank and salary would depend chiefly upon research productivity' (Stewart 2006). (The use of 'his' in phrasing this commitment is certainly to be excused, given the mores of the times).

This led to a situation where successful teaching, and enthusiastic student evaluations, are certainly valued by universities; but evaluations for promotion and tenure are likely to be focused almost completely on research (Boyer Commission on Educating Undergraduates in the Research University 1998).

In 'Scholarship reconsidered', Ernst Boyer discusses the way the work of the academy has changed throughout the years - 'moving from teaching, to service, and then research, reflecting shifting priorities both within the academy and beyond' (Boyer 1990, xi), and the main focus is the identification of the functions of professors as including discovery, integration, application and teaching. Boyer discusses the relevance, value and 
interdependency of these functions '... We need scholars who not only skillfully explore the frontiers of knowledge, but also integrate ideas, connect thought to action, and inspire students ...' (Boyer 1990, 77). His work is followed by the International Society for the Scholarship of Teaching and Learning (ISSOTL), contributing to a larger movement towards recognition of the value of teaching. As stated by the Boyer Commission on Educating Undergraduates in the Research University (1998) 'The department head when making salary recommendations may look almost exclusively at the grants or publication record. The junior faculty member who seems to give dis-proportionate time and attention to freshman/sophomore courses may well be counseled toward more "productive" redirection ...'. Also, '... Universities rightly assume that whoever appears in front of their classrooms can command the material that should be conveyed. Rare individuals can also captivate and stimulate student audiences, large and small, with their dynamic classroom presentations. Since it is likely that most universities will need to retain some large classes, those individuals capable of striking success in the classroom should be suitably rewarded. Recognition as distinguished teacher-scholars should include added remuneration ...'.

The emphasis on research and on graduate training devalues undergraduate education, as noted by Katz $(2002)^{13}$ who identifies the creation of teaching centers and other mechanis ms as answers to the obvious need to improve the undergraduate education. At FEUP, mention should again be made of the Laboratório de Ensino e Aprendizagem (LEA). LEA promotes and supports initiatives that contribute to creating a culture of quality in teaching and success in learning, essential for the competitiveness of FEUP. It also aims at supporting FEUP's community with research/intervention in the area of engineering education.

Reinforcing the notion that merit of teaching is the delta $x$ students earn, it is clear however that for an institution aiming at being a research HE institution - as FEUP - the level of students at entry is a critical issue. Translating from the Portuguese '... As for students: the merit of teaching is always the 'delta $x$ ' of progress in student education. To teach an illiterate how to read and write is, without any doubt, a task of great merit that ennobles those who practice it.

But at FEUP, it doesn't just matter 'delta $x$ ', the starting point for admitting students also matters a lot, since - in general - the better this starting point, the greater the probability that the students actually benefit from the opportunities available at FEUP. It is therefore important that candidates present the best academic credentials at the time of admission ...' (Carvalho et al. 2015).

Traditionally grades are an important fact of life at universities. They should reflect the understanding reached by students in each subject of their degree, and help their awareness of strengths and weaknesses. There seems to be a general perception of grade inflation. In the USA, already in 2002 Rosovsky and Hartley (2002) addressed this problem. They note that unlike in price inflation, which may rise indefinitely (as the Germans well know...), grade inflation is constrained by $\mathrm{A}$, or 20 , or 100 or whatever maximum grade each national system

\footnotetext{
13 As a sideline, the institution of Katz, the Woodrow Wilson School of Public and International Affairs of Princeton University, was renamed Princeton School of Public and International Affairs. According to The New York Times, June 27,2020 '... Unive rsity trustees concluded that Wilson's "racist thinking and policies make him an inappropriate namesake for a school or college," Princeton's president said on Saturday...'. https://www.nytimes.com/2020/06/27/nyre gion/princeton-universitywoodrow-wilson.html.

This is yet a nother case of the reconsideration of historical celebration and honours, as also seen e.g. in Bristol with the drowning of the statue of philanthropist and slave tra der Edward Colston.
} 
uses. With inflation, there is compression at the upper end of the scale. In the access to Mechanical Engineering integrated Master at FEUP, Figure 6 tells the story:

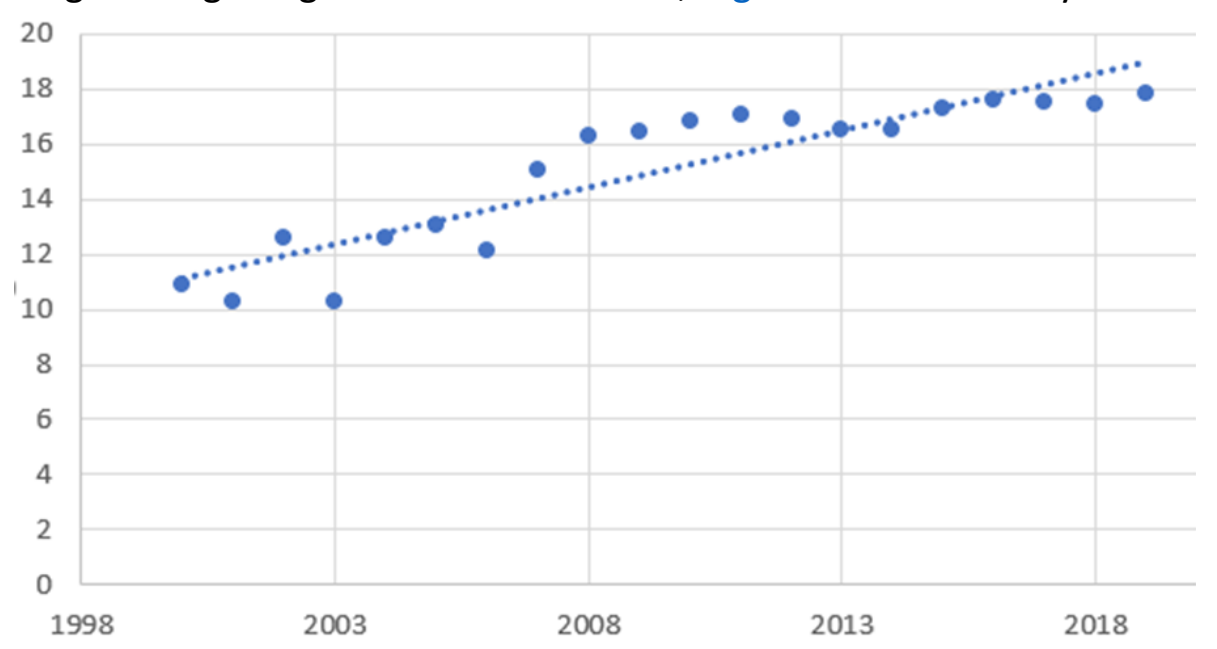

Figure 6: Lowest entrance mark for students admitted to the Mechanical Engineering (since 2006 the integrated master degree of FEUP; for 2000-2006 the earlier 5 years licenciatura)

Is the increasing entrance grade a result of increasing attractiveness of Mechanical Engineering? Maybe, given the peculiar circumstances of Portuguese development, with an emphasis on Civil Engineering in the XXth century, a period of insufficient industrialization in the second half of that century, and a trend for de-industrialization in the turn of the millennium. Perhaps the consequences of the premature emergence of a Portuguese economy based on services, and the economic crisis started in 2009, created an awareness for the importance of production and exportation of tradable goods, implying a growing popularity of the Mechanical Engineering education given its role in these possible industrial developments. Another aspect could be the variation of numeri clausi, but this certainly does not play a role in the grade inflation at entrance, because there was never a reduction of such numeri clausi, on the contrary small increases have been regularly adopted.

Students and their needs and problems, administrations and their voracious need for paperwork; bureaucracy, funding agencies and their un-predictability, colleagues with rather diverse characters and behaviours, all this makes the life of professors a varied albeit usually exhausting one. No wonder that the academic career is prone to bad moments, drawbacks and even burnout. This is vividly presented by Nieto (1989) in a very funny paper describing the typical day of a highly conscientious professor. I believe that this article is only available in Portuguese (it was published in a special issue of Revista Crítica de Ciências Sociais celebrating the 700 years of the Universidade de Coimbra), but thanks to the progress, interested nonPortuguese speaking readers may get an appreciation just using Google Translator! In some extreme cases of burnout - or indeed intrinsic personal characteristics - life in academe can evolve to unexpected waters. In Portuguese public TV, recently (SIC 2020) the following dialogue could be heard: Journalist: ... sometimes to be heard you must pound fist on table ...: Professor Constantino Sakellarides ${ }^{14}:$... in academe it is not used to punch, our business is knowledge ...'. Indeed! But nevertheless cases are known of boxing among academic staff, as cheerfully described by an ex Rector of University of Lisbon in his memoirs ... (Fernandes 2006, 266).

\footnotetext{
14 Portuguese medical doctor expert in public health.
} 


\section{Conferences}

Meeting face to face may help to create synergies and conditions for joint ventures; that is important, particularly in engineering where most research involves large teams of people (further, of course, to a modicum of cash and organization). During many years, conferences were held in locations associated to recognized or at least potential developments in the conference topic. This logical choice was progressively extended to include exotic locations, tropical islands, and the like. Since most of the associated travel costs are paid for by public funds, this seems to me a bit abusive, since it is not really clear what is the component of work and the component of merry making, and public funds are not called for in the second one. Academics dazzled by travelling are frequently found. This was observed with great verve by David Lodge, in his hilarious 1984 best seller 'Small World', where the fictitious Professor Morris Zapp observes sharply, in dialogue with the other fictional character, the young Persse McGarrigle (the year 1984 should be recalled here): '.... said Morris Zapp, [...] "information is much more portable in the modern world than it used to be. So are people. Ergo, it's no longer necessary to hoard your information in one building, or keep your top scholars corralled in one campus. There are three things which have revolutionized academic life in the last twenty years, though very few people have woken up to the fact: jet travel, direct-dialling telephones and the Xerox machine. Scholars don't have to work in the same institution to interact, nowadays: they call each other up, or they meet at international conferences.

And they don't have to grub about in library stacks for data: any book or article that sounds interesting they have Xeroxed and read it at home. Or on the plane going to the next conference. I work mostly at home or on planes these days. I seldom go into the university except to teach my courses."

"That's a very interesting theory," said Persse. "And rather reassuring, because my own university has very few buildings and hardly any books."

"Right. As long as you have access to a telephone, a Xerox machine, and a conference grant fund, you're OK, you're plugged into the only university that really matters - the global campus. A young man in a hurry can see the world by conference-hopping"...' (Lodge 1984, 43-44).

'... The modern conference resembles the pilgrimage of medieval Christendom in that it allows the participants to indulge themselves in all the pleasures and diversions of travel while appearing to be austerely bent on self improvement.

To be sure, there are certain penitential exercises to be performed - the presentation of a paper, perhaps, and certainly listening to the papers of others. But with this excuse you journey to new and interesting places, meet new and interesting people, and form new and interesting relationships with them; exchange gossip and confidences (for your well worn stories are fresh to them, and vice versa); eat, drink and make merry in their company every evening; and yet, at the end of it all, return home with an enhanced reputation for seriousness of mind. Today's conferees have an additional advantage over the pilgrims of old in that their expenses are usually paid, or at least subsidised, by the institution to which they belong, be it a government department, a commercial firm, or, most commonly perhaps, a university (Lodge 1984; ShoaffBallanger and Davis 1992).

All this involves quite a lot of air travel, and this is a well-known culprit in generating $\mathrm{CO}_{2}-$ per $\mathrm{km}$ per passenger, at least of the order of 4 times that of a train (BBC 2019). This is aggravated by the contrails, those seemingly innocent condensation trails that jets leave at high altitude (Hambling 2021; Teoh et al. 2020). 
David Lodge is the subject of scholarly studies; I just notice the doctoral thesis of M. Shanthi submitted to Goa University (Shanti 2017). Goa and her historical links to Portugal also hints to globalization, and globalization is of course the topic of Lodge's book. By the way, Portugal's role in globalization should be recalled and celebrated here, see e.g. Rodrigues and Devezas (2009).

The Goa University thesis of M. Shanti also quotes ipsis verbis from Lodge the following juicy observation '... The whole academic world seems to be on the move. Half the passengers on transatlantic flights these days are university teachers. Their luggage is heavier than average, weighed down with books and papers - and bulkier, because their wardrobes must embrace both formal wear and leisurewear, clothes for attending lectures in, and clothes for going to the beach in, or to the Museum, or the Schloss, or the Duomo, or the Folk village. For that's the attraction of the conference circuit: it's a way of converting work into play, combining professionalism with tourism, and all at someone else's expense. Write a paper and see the world! ...' (Lodge 1984, 231; Shanti 2017, 17).

The above excerpts illustrate vividly the fact that up-to-date technology of the eighties, e.g. faxes, is nowadays no longer used or perhaps not even known by youngsters. We tend to feel that it is now that life-changing novelties are occurring, but that was certainly the feeling of our predecessors. The only difference is the rate of appearance of novelties as results from their exponential growth. This growth goes hand in hand with the explosion of population, as vividly reminded by Nobel laureate Robert Fogel, Figure 7 (Fogel 1999). A revisit to Malthus (1826) 'An Essay on the Principle of Population' seems advisable...

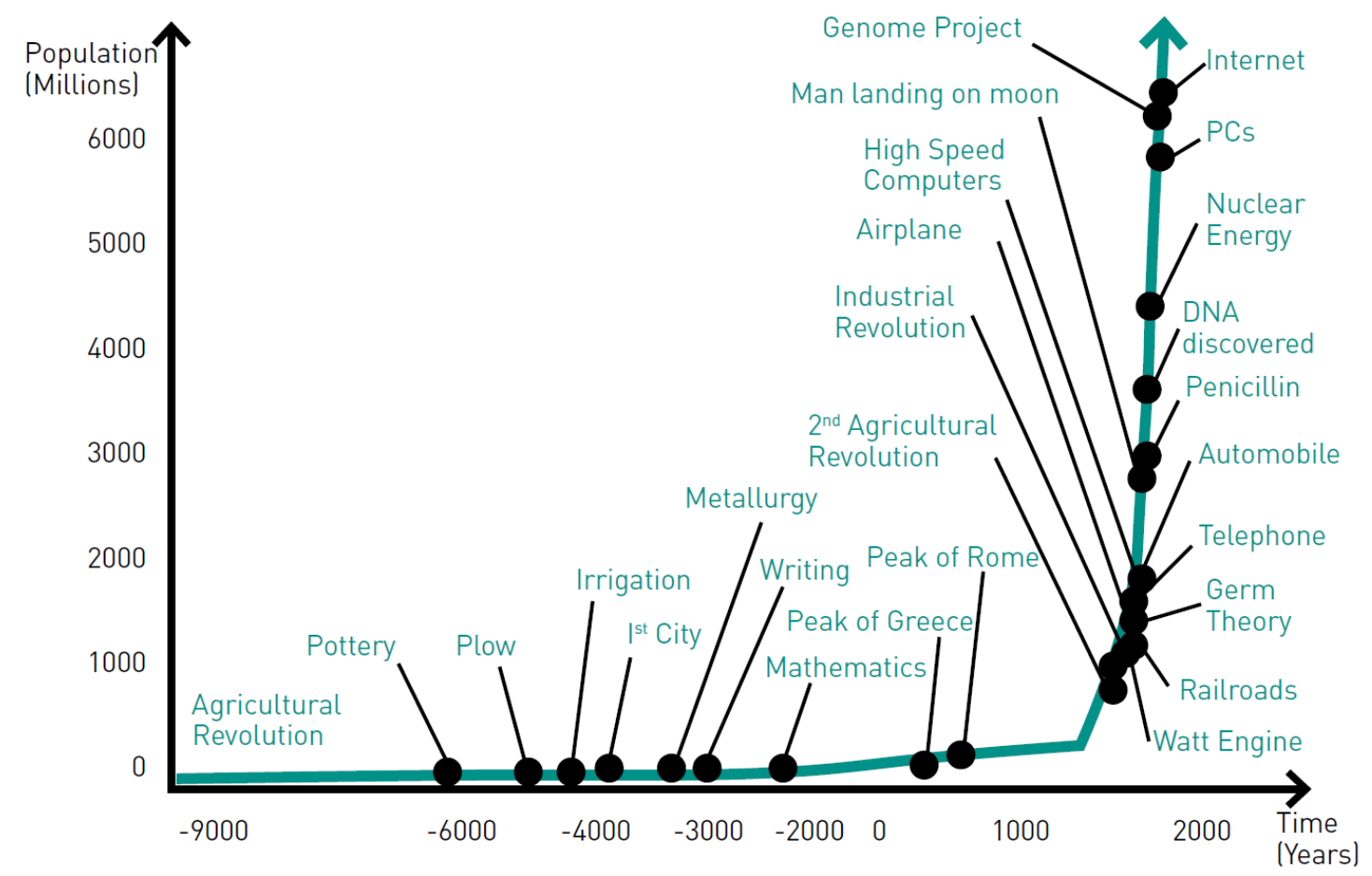

Figure 7: Figure from Robert W. Fogel, March 1999, 'Catching Up with the Economy', The American Economic Review, vol.89, no. 1: 1-21, as adapted by Burrows (Fogel 1999)

The philosophical aspects of this are well discussed by Maël Renouard (Renouard 2016, 2017, 2020) who observes that the more data had to be processed and mastered, the more recourse was had to hierarchical, pyramidal classification, proceeding by subdivisions, tree structures, etc. To find something, it had to be stored somewhere. Disorder was the enemy of memory. And value was given to individuals with encyclopedic, organized knowledge - or at least more 
information than the average joe. My initial professional years took place under that paradigm. That is changed forever: no longer good memory and encyclopedic information is valuable when our cellular phone answers most of the information needs.

We use, on the Internet, an immense externalized memory which is made available without any organization or order (Renouard 2017). What is valuable now is the ability to relate facts, concepts, data and tools, much more than an encyclopedic knowledge of some field.

\section{Publication}

In the first half of the twentieth century, scientific journals were mainly published by the scientific and academic institutions themselves (universities, learned academies, research laboratories, etc.). Typically, these journals were exchanged free of charge among the interested institutions. In this context FEUP had its own printed Revista, which finished long ago (1974 I believe; I recall seeing it in the Imperial College library when I started my Applied Mechanics master in 1975). It should be noted that some institutions always kept this format, like the Bulletin of Universitatea Politehnica din București, or Periodica Polytechnica Mechanical Engineering published by the Faculty of Mechanical Engineering of the Budapest University of Technology and Economics, or Mechanika published by Kaunas University of Technology. And recently, under the leadership of Professor Lucas da Silva, FEUP restarted his scientific journal, now online only, titled U.Porto Journal of Engineering. All of the above are open access journals, made for the sake of scientific and technological development, without the intention of making a buck out of the hard work of others.

Although private science publishers have existed for long, e.g. Springer (Julius Springer founded Springer-Verlag in Berlin in 1842), with Robert Maxwell ${ }^{15}$ and Pergamon a business model was created that led to todays' Elsevier $^{16}$ and the like. A notable current trend is open access. Open access science and publication is being promoted by the EU (EC, n.d.), e.g, Oscar project for open science in European aviation research. This trend, together with the perceived greed of some large global publishers, and the appearance of file exchange sites as sci-hub and libgen are impacting the publishing world, which is likely to see substantial changes in the near future.

Growing number of authors per article published, as in certain areas of Physics, lead to a loss of meaning for Hirsch's h index (Hirsch 2005), as discussed by Koltun and Hafner (2021). They found that the effectiveness of scientometrics is declining, as illustrated by the correlation of the h-index with scientific awards in Physics: this dropped from 0.34 in 2010 to 0.00 in 2019!

So far, we can observe a deluge of publications, with the impossibility for a researcher of following even a modicum of what is being published in his/her own field. And this goes together the emergence of a sector of so-called predatory publishing, firstly studied in detail by Jeffrey Beall ${ }^{17}$, that offers avenues for non-peer reviewed publication of indeed any trash, augmenting the deluge with the increasing problem of uncontrolled unedited actors and outcomes.

Pan et al. (2018) note that '... The decreasing attention to recent literature published within the last 6 years suggests that science has become stifled by a publication deluge destabilizing the balance between production and consumption ...' They assume that there is a cognitive

\footnotetext{
15 Wiki pedia, s.v., "Robert Maxwell”, last modified July 23, 2021, 04:59, https ://en.wikipedia.org/wiki/Robert_Maxwell.

16 Wiki pedia, s.v., "RELX”, last modified July 20, 2021, 03:25, https://en.wikipedia.org/wiki/RELX.

17 Wiki pedia, s.v., "Pre datory publishing", last modified July 15, 2021, 10:55,

https://en.wikipedia.org/wiki/Predatory_publishing.
} 
limit for a researcher, implying that he/she must necessarily narrow the breadth but also the depth of knowledge as a consequence of the publication deluge. In parallel, citations grow exponentially, with the growth in some cases fueled by practices of intense self-citation, or even 'citation farms' as discussed in Nature recently (Van Noorden and Chawla 2019; loannidis et al. 2019).

Open access online journals are of course a good thing. But it is also true that the cost of the subscriptions of some commercial publishers covers the expectation of professional services as (i) permanent availability of content (ii) duly subject to proper peer review, and (iii) organized in a convenient searchable fashion. Journals made by organizations without the resources of big publishers - as many research institutions or scholarly societies - may be prone to disappearance. In a recent article in Science, Brainard (2020) notes that many scientific journals have vanished from the world wide web, and no one preserved them! (again, my earlier reference to ancient papyri that are still legible comes to mind). The big commercial publishers are often also criticized for earning their profits from research paid for mostly by public money. They also benefit from the free expert labour provided by the reviewers that give their expertise to ensure that what gets to be published is worthwhile. An issue associated with this is the possibility of referees being rewarded in cash or some other meaningful tangible form. This is however the object of great controversy (Squazzonia, Bravo, and Takács 2013), since the moral aspects of referees' work may be jeopardized by such payments. Nevertheless, others say'l cannot express how incredibly uncontroversial it is to ask for money to perform skilled work' (Browne 2020).

In the context of refereeing, the appearance of the database PUBLONS that collects data on the peer review activities of each individual researcher is to be warmly welcomed. Obviously no payments to reviewers are made by the database, but at least their almost always anonymous expert labour is duly recognized, making public the contributions of each one to this rather important aspect of science.

Given the widespread access of databases as Web of Science and Scopus, the publish or perish mentality evolved throughout the years to more sophisticated formats. Hirsch's $h$ index is solely a basic concept in a growingly complex and vast array of bibliometric tools, that sometimes are used to decide who gets hired and who does not gets hired for new academic posts. In some extreme cases of misuse, those metrics may become a proxy rendering unnecessary serious reading of the candidates output by the jury!

\section{Accreditation, recognition, rankings}

In their 2012 paper Froyd, Wankat, and Smith (2012) identify five major shifts in engineering education in the past one hundred years:

- from hands-on practical focus, to engineering science and analysis;

- outcomes-based education and accreditation;

- emphasis on engineering design;

- increasing awareness and use of education, learning, and social-behavioral sciences research;

- integration of information and communications technologies (ICT) in education.

and note that whilst the first two already occurred, the latter three are in progress, with formats not yet settled and impacts on practice still evolving.

What should be the student outcomes? from ABET, General Criteria for Baccalaureate Level Programs (ABET 2019) 
'... Attainment of these outcomes prepares graduates to enter the professional practice of engineering...

1. an ability to identify, formulate, and solve complex engineering problems by applying principles of engineering, science, and mathematics.

2. an ability to apply engineering design to produce solutions that meet specified needs with consideration of public health, safety, and welfare, as well as global, cultural, social, environmental, and economic factors.

3. an ability to communicate effectively with a range of audiences.

4. an ability to recognize ethical and professional responsibilities in engineering situations and make informed judgments, which must consider the impact of engineering solutions in global, economic, environmental, and societal contexts.

5. an ability to function effectively on a team whose members together provide leadership, create a collaborative and inclusive environment, establish goals, plan tasks, and meet objectives.

6. an ability to develop and conduct appropriate experimentation, analyze and interpret data, and use engineering judgment to draw conclusions.

7. an ability to acquire and apply new knowledge as needed, using appropriate learning strategies.'

Of course the list above reflects the requirements of a particular organization, ABET. The list seems however to be rather consensual also for programs not seeking ABET accreditation.

Programs seeking accreditation by ABET should show compliance with the applicable general criteria and specific program criteria established by the program's lead society (e.g., AIAA, ASCE, IEEE, ASME, etc.)

At master lever, further to general criteria ABET provides criteria that vary according to the topic. For ex., Program criteria for engineering mechanics and similarly named engineering programs (lead Society: ASME)

'... These program criteria apply to engineering programs that include "mechanics" or similar modifiers in their titles.

\section{Curriculum}

The program curriculum must require students to use mathematical and computational techniques to analyze, model, and design physical systems consisting of solid and fluid components under steady state and transient conditions.

\section{Faculty}

The program must demonstrate that faculty members responsible for the upper-level professional program are maintaining currency in their specialty area.'

The program criteria for mechanical and similarly named engineering programs (lead Society: ASME), include the same point 2. concerning faculty, but regarding curriculum says:

'... 1. Curriculum

The curriculum must require students to apply principles of engineering, basic science, and mathematics (including multivariate calculus and differential equations); to model, analyze, design, and realize physical systems, components or processes; and prepare students to work professionally in either thermal or mechanical systems while requiring topics in each area ...'. There is a tension between the increasing body of knowledge and the constraints of time, together with the recognition that young engineers should possess a range of personal characteristics that enable them to function in real engineering teams. 
In the past, practicing engineers or faculty with previous industrial experience had a major role in the education of young engineers; this was mainly practice based. Meanwhile engineering education evolved to a paradigm of science and analysis, with many faculty having solely research experience in academe, and no industrial experience at all. This requires that the curriculum be designed to give experience in conception, design, implementation, and operation of systems, precisely the objectives of CDIO (Conceiving - Designing Implementing - Operating) framework that aims to answer that challenge. CDIO stresses engineering fundamentals set in the context of real systems and products, and has been used throughout the world by institutions for curricular planning and outcome-based assessment. In Portugal the Instituto Superior de Engenharia do Porto (ISEP) is a member of the CDIO initiative, and organized the 2016 CDIO Fall Meeting.

Further to outcomes, objectives must be clearly spelled out. Bloom et al. (1956), and Krathwohl, Bloom, and Masia (1964) presented a taxonomy that is used to formulate learning objectives. According to Bloom's taxonomy, learning is divided into three domains, cognitive, affective and psychomotor. This is discussed in detail in a CDIO report by Crawley (2001). Wankat and Oreovicz (1993) note that the taxonomy in the cognitive domain (Bloom et al. 1956) has been widely adopted, whereas the taxonomy in the affective domain (Krathwohl, Bloom, and Masia 1964), which includes interest, attitudes, and values, has been less influential. The 1956 Handbook 1 was up-dated in 2001 (Anders on et al. 2001).

In a wide-breadth statement, Charles Vest (MIT President, 1990 - 2004, President of the National Academy of Engineering, 2007 - 2013) answered the question of what is important in engineering education as follows: '... Making universities and engineering schools exciting, creative, adventurous, rigorous, demanding, and empowering environments is more important than specifying curricular details ...' (Vest 2008).

Ranking of universities is nowadays big business, even leading to consolidation of several universities into a single large one in order to improve the indicators used by the ranking organizations. Apparently this may be a strong incentive for such moves, even if synergies etc. may also be invoked in favor of the amalgamation (The Economist 2020).

Many years ago the rankings were more innocent, as for example the first ranking of European Universities, published in 1989 by the French newspaper Libération, Figure 8, (Les 100 Meilleures Universites en Europe 1989). This was expressly made with the intention of facilitating the choice of university for students involved in ERASMUS mobility. The ERASMUS programme, one of the true successes of the European Union, was created in 1987, and paved the way for the Bologna declaration of 9 June 1999, signed on behalf of Portugal by Eduardo Marçal Grilo, that created conditions for increased mobility and interaction thanks to the adoption of mechanisms as the ECTS (acronym of the European Credit Transfer and Accumulation System), easily readable and comparable degrees, and adoption of a system essentially based on two main cycles. 


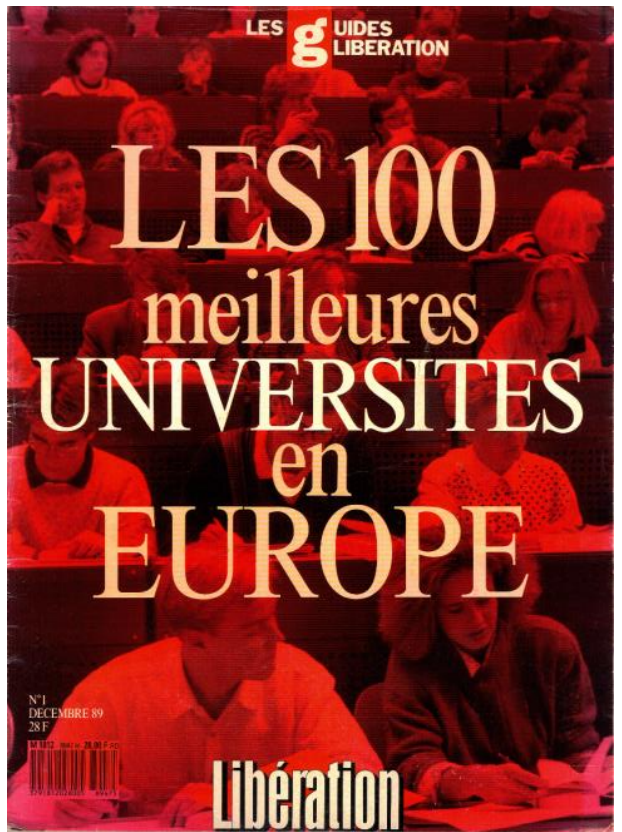

Figure 8: Cover of the Libération ranking of Dec. 1989

Other noteworthy early rankings were those of Der Spiegel ("Uni-test Europa"1998), Figure 9.

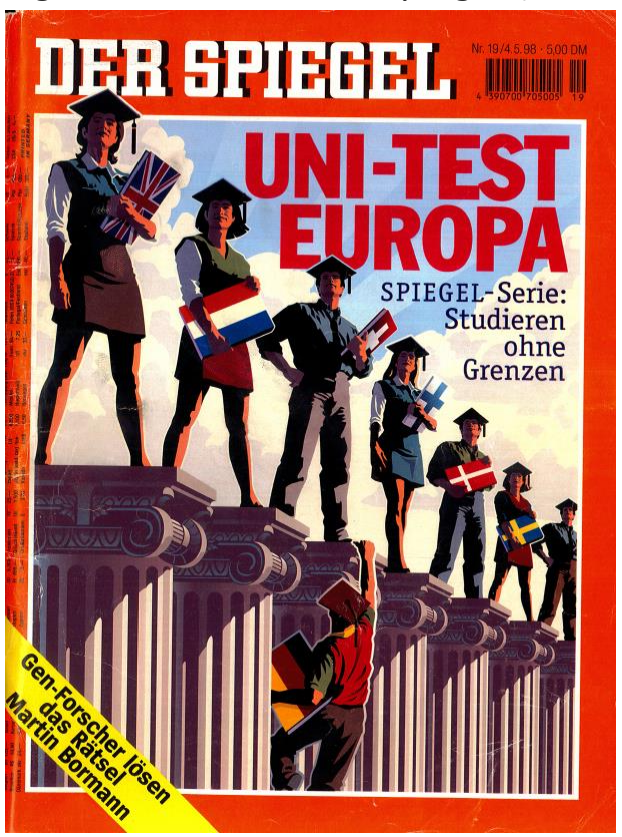

Figure 9: Der Spiegel, May 4, 1998

Among the rankings that currently deserve great attention, at least of the administration of universities, is the Academic Ranking of World Universities (ARWU) commonly known as Shanghai Ranking. Criticism of Shanghai Rankings includes the weight given to research often performed decades ago (it includes for ex. Nobel prize winners in its algorithm, and the Nobel prize may be an old one celebrating even older achievements...), it may be a motivation for merging universities into larger ones, and uses metrics that are not independent of university size. For example, as universities amalgamate number of publications are just added, implying that a merger between two similarinstitutions creates a new one with better indicator values, without any change in quality!

Bill Destler, the President of Rochester Institute of Technology points out that rankings are used to create "essentially meaningless "winners" and "losers" (Destler 2013). Instead of looking for Nobel prizes and the like, the quality of an institution should be evaluated 
considering its mission and the success in achieving that mission. Rankings also do not favor diversity in higher education, which is certainly a disservice to the public, given that higher education should be as diverse as diverse are the needs of society.

From a UNESCO 2013 publication (Marope, Wells, and Hazelkorn 2013, 18), '... The 15,000+ institutions around the world that have not, do not and will not appear on any 'top' list of universities continue their noble pursuits of educating and nurturing learners hungry for knowledge and skills; of contributing to the development of human and social capital; and of undertaking important research for sustainable futures. Obsessing about joining and climbing a league table or becoming 'world-class' ignores the greater role, purpose and mission of higher learning institutions'.

Focusing on The Times Higher Education rankings, Shay (2018) observes that '... assessing the quality of teaching in ways that can be standardised and compared isn't simple. That's why we often end up valuing what we can measure, instead of measuring what we value ...'.

Closing this section, it is fitting to revisit Clark Kerr and his California Master Plan for Higher Education (Kerr 2001): as mentioned before, this conceived a higher education system based upon three public higher education segments, each one concentrating in his particular mission and remit, naturally seeking excellence within its own particular set of responsibilities. It would be ridiculous to evaluate and rank all of them according to the same set of indicators and criteria!

\section{Engineering education research; societies}

The subject of engineering education is served by several high profile learned societies, as ASEE - the American Society for Engineering Education, which publishes the magazine Prism and the Journal of Engineering Education, and SEFI, the Société Européenne pour la Formation des Ingénieurs which publishes the European Journal of Engineering Education. Further to these, many other societies, national and regional, publish research, news and commentaries on engineering education (List of Engineering Education Journals 2015).

For an in depth discussion of the paths pursued by the research on engineering education the reader is directed to informative papers by Borrego and Bernhard (2011), and Lima and Mesquita (2018). There is even a leaflet on 'How to Publish in Engineering Education', with advice on points to consider when conducting engineering education research (Chan 2015). In Portugal the SPEE - Sociedade Portuguesa para a Educação em Engenharia was created in 2010. This could suggest that interest for study and research on engineering education would be a recent endeavor in this country. That is certainly not true; for example a major conference was held in 1962 ("Relatos das Sessões de Trabalho" 1962; Congresso do Ensino de Engenharia 1968) with leadership of the Portuguese universities with major engineering programs (FEUP and IST). The Congressos da Ordem dos Engenheiros (OE) typically include engineering education, e.g. 1977, 88, 94, ...; OE and FEANI organized in 1981 the seminar 'A Formação Académica e Prática dos Engenheiros e dos Técnicos', and in 2003 the 31st SEFI conference took place in FEUP, when SEFI's Leonardo da Vinci Medal was awarded to FEUP's Professor Joaquim Sarmento. The role of Manuel Rocha during the fifties and up to the seventies of the last century should also be recalled here. He was president of the Ordem dos Engenheiros and director of Lisbon's LNEC, the Laboratório Nacional de Engenharia Civil, an institution that under his leadership reached high international reputation, and used those high offices to contribute to and promote engineering education in Portugal. Other details concerning engineering education in Portugal may be found in publications resulting from a major 
engineering exhibition which took place in Lisbon in 2003 (de Brito, Heitor, and Rollo 2002; Heitor, de Brito, and Rollo 2004; Heitor et al. 2003).

\section{Collaboration vs. individualism}

Limits to growth was a subject put on the agenda by the Club of Rome, with a groundbreaking publication in 1972 (Meadows et al. 1972; Yáñez-Arancibia et al. 2013). Even if the methodology for quantitative forecasting may be now outdated, that work had a profound impact in raising awareness for ecology and for sustainability. Recent works in these fields include those of Santos (2020) who recently published a major work in this field 'Time, Progress, Growth and Technology: How Humans and the Earth are Responding' (Santos 2021). Important contributions for this awareness are, on the positive side, those of Pope Francis with his third encyclical, "Encyclical letter - Fratelli Tutti" (2020), which delivers an impressive and well-grounded lesson on sustainability and our duties for continued good life on earth; and, on the negative side, the contributions of the ex-president of the USA, Trump with his nefarious negation of scientific evidence and contempt for multilateral collaborative efforts for dealing with climate change.

I already alluded to the divide between people that look forward only, and people attracted by history and things past. I met many forward looking individuals in my professional life, and I respect very much their capacity to get things done; but I confess my interest and curiosity for the past, since I believe that it helps to understand the present and to build the future. I respect archives and the like, which is an inclination frowned upon by my forward looking colleagues ... Another divide concerns individualism versus collective effort. From Lidicker Jr. (2020), 'We must explicitly recognize the need for an appropriate mixture of altruistic and selfpromoting social behaviors. The first of these benefit the sociopolitical groups to which we belong (the common good), and the second group of behaviors supports the individual welfare of each of the citizens that constitute those groups' and 'to promote democracy unequivocally requires a balance of the two modes of social behavior'.

Addressing individualism, in section \#105 of 'Fratelli Tuti', Pope Francis ("Encyclical letter Fratelli Tutti" 2020) writes '... Individualism does not make us more free, more equal, more fraternal. The mere sum of individual interests is not capable of generating a better world for the whole human family. Nor can it save us from the many ills that are now increasingly globalized. Radical individualism is a virus that is extremely difficult to eliminate, for it is clever. It makes us believe that everything consists in giving free rein to our own ambitions, as if by pursuing ever greater ambitions and creating safety nets we would somehow be serving the common good'.

Trumbul, Rothstein-Fisch, and Greenfield (2000) discuss individualism versus collectivism in the USA in the perspective of different cultural backgrounds and sets of values, pointing out that individualism is representative of prevailing US culture, whereas collectivism is representative of many immigrant cultures. And as regards group creativity, Goncalo and Staw compare the collectivistic groups versus individualistic groups, and conclude that 'individualistic groups instructed to be creative are more creative than collectivistic groups given the same instructions. These results suggest that individualistic values may be beneficial, especially when creativity is a salient goal'.

In academe, the discussion may include ethical aspects, cheating in particular. In 'Teaching Engineering', Wankat and Oreovicz (1993, 237-38) discuss cheating, and in this context touch the individualism versus collaboration divide: '... Procedures for homework, projects, and takehome tests are similar, [...]. Making any of these assignments a large part of the grade, 
particularly in a class where there is no rapport between the professor and the students, is asking for trouble.

If a take-home assignment is to be done independently, this needs to be discussed in class and it needs to be stated in writing on the top of the assignment. Despite this, collaboration on take-home assignments is very high [...]. Even graduate students collaborate on take-home tests. The rules for plagiarism of papers need to be clearly spelled out. A student who believes that he or she will receive more credit by properly citing sources is less likely to plagiarize. The easiest way to decrease cheating on take-home assignments is to make them a small percentage of the course grade and then encourage students to collaborate".

And what about careers in academe? From Kemp (2003) '... Is it better for me to work alone and create a name for myselfas an innovative scholar who has carved out a recognizable niche for myself, or do I collaborate with my colleagues from this institution and other institutions to combine specialties and increase productivity at the expense of individuality and personal acclaim? Which avenue will prove to be most beneficial to my career and my aspirations to become a full professor at some point in the probably distant future? ....'. It is certain that many areas of research, particularly those involving experimentation, require the collaboration of many actors; not so much in numerical or purely theoretical work. But whatever the type of research, the two attitudes - individualistic and collaborationist - may happen. The same happens with teaching. It is my opinion that nowadays the academic career and performance evaluations impose upon young staff an individualistic behaviour, and in my view that is rather detrimental to the synergies and accomplishments that collaborative efforts could achieve. I stand clearly on the side of collaboration. But this is of course an unfinished discussion. Like engineering education!

\section{References}

ABET. 2019. "Criteria for accrediting Engineering Programs, 2020 - 2021". https://www.abet.org/accreditation/accreditation-criteria/criteria-for-accreditingengineering-programs-2020-2021/.

Anderson, L. W., D. R. Krathwohl, P. W. Airasian, K. A. Cruikshank, R. E. Mayer, P. R. Pintrich, J. Raths, and M. C. Wittrock, eds. 2001. A Taxonomy for Learning, Teaching, and Assessing. A Revision of Bloom's Taxonomy of Educational Objectives. Abridged edition. Addison Wesley Longman.

Archibald, R. B., and D. H. Feldman. 2010. Why does college cost so much?. Oxford University Press. https://scholarworks.wm.edu/asbook/33.

ASME. n.d. "Ethics in Engineering". https://www.asme.org/about-asme/governance/ethics in-engineering.

BBC. 2019. "Climate change: Should you fly, drive or take the train?". https://www.bbc.com/news/science-environment-49349566.

Birnbaum, R. 2000. Management fads in Higher Education: Where they came from, what they are, why they fail. Jossey-Bass.

Bloom, B. S., M. D. Englehatt, E. J. Furst, W. H. Hill, and D. R. Krathwohl. 1956. Taxonomy of Educational Objectives: Handbook I - Cognitive Domain. David McKay Company, Inc.

Borrego, M., and J. Bernhard. 2011. "The emergence of engineering education research as an internationally connected field of inquiry". Journal of Engineering Education 100, no. 1: 1447. https://doi.org/10.1002/j.2168-9830.2011.tb00003.x. 
Boyer Commission on Educating Undergraduates in the Research University. 1998. Reinventing undergraduate education: A blueprint for America's research universities. U.S. Department of Education. Office of Educational Research and Improvement. Educational Resources Information Center (ERIC).

Boyer, E. L. 1990. Scholarship reconsidered: Priorities of the professoriate. The Carnegie Foundation for the Advancement of Teaching.

Brainard, J. 2020. "Dozens of scientific journals have vanished from the internet, and no one preserved them". Science, September 8, 2020. https://doi.org/10.1126/science.abe6998.

Browne, G. 2020. "Researcher leads drive for peer reviewing to be paid assignment". Times Higher Education, October 2020. https://www.timeshighereducation.com/news/researcher-leads-drive-peer-reviewing-bepaid-assignment.

Butler, G. M. 1963. "Scientists in industry: Conflict and accommodation, Will iam Kornhauser". $\begin{array}{lllll}\text { Research Management } \quad \text { 6, no. } & \text { 96-98. }\end{array}$ https://doi.org/10.1080/00345334.1963.11755643.

Carvalho, A. S., J. P. Pêgo, J. F. Oliveira, L. A. Ferreira, P. Garcia, and P. T. de Castro. 2015. Contribuição para a elaboração de um plano estratégico para a FEUP, com o horizonte temporal de 2035. Ensino e aprendizagem - Análise SWOT, October 29, 2015.

Chan, C. K. Y. 2015. How to Publish in Engineering Education. Engineering Education Enhancement and Research Asia (E3R Asia). https://tlerg.cetl.hku.hk/wpcontent/uploads/2017/03/e3r-inserts-publish.pdf.

Committee on Higher Education. 1963. Higher Education - Report of the Committee appointed by the Prime Minister under the Chairmanship of Lord Robbins presented to parliament by the Prime Minister by Command of Her Majesty. TD/TNC 115.570. Her Majesty's Stationery Office. http://www.educationengland.org.uk/documents/robbins/robbins1963.html.

Congresso do Ensino de Engenharia. 1968. "O ensino de Engenharia: Contribuição para a sua reforma". Análise Social 6, no. 22/24: 763-84. http://www.jstor.org/stable/41008323.

Crawley, E. F. 2001. The CDIO Syllabus: A statement of goals for undergraduate engineering education. Department of Aeronautics and Astronautics, Massachusetts Institute of Technology http://cdio.org/framework-benefits/cdio-syllabus-report.

de Brito, J. M. B., M. Heitor, and M. F. Rollo, eds. 2002. Engenho e Obra: Uma abordagem à história da Engenharia em Portugal do século XX. Dom Quixote.

de Castro, P. M. S. T. 1996. "Ensinar Engenharia: Profissão e Ética". https://sigarra.up.pt/up/pt/conteudos_service.conteudos_cont?pct_id=10203\&pv_cod=3 OHawaT7aaas.

de Castro, P. M. S. T. 1999. "Engineering ethics in engineering education: a Portuguese experience". Paper presented at the Conference on Ethics in Engineering and Computer Sciences, Cleveland, Ohio, March 1999. http://ethics.iit.edu/eelibrary/node/7569.

de Castro, P. T., and R. Guimarães. 2012. "FEUP homenageia Prof. Vasco Sá". Engenharia: Boletim Informativo da Faculdade de Engenharia da Universidade do Porto no. 51: 34-35. https://issuu.com/feup/docs/revistaengenharia51.

Destler, B. 2013. "The ultimate absurdity of college rankings". HUFFPOST, May 10, 2013. https://www.huffpost.com/entry/the-ultimate-absurdity-of_b_3247841. 
Didier, C. 2000. "Engineering ethics at the Catholic University of Lille (France): Research and teaching in a European context". European Journal of Engineering Education 25, no. 4: 32535. https://doi.org/10.1080/03043790050200368.

E4C. n.d. "Engineering for change". https://www.engineeringforchange.org/.

EC-European Commission. 2020. Digital Education Action Plan 2021-2027: Resetting education and training for the digital age. Brussels: European Commission. https://ec.europa.eu/education/education-in-the-eu/digital-education-action-plan_en.

- 2021. "Digital Education Action Plan (2021-2027)". https://ec.europa.eu/education/education-in-the-eu/digital-education-action-plan_en.

- - n. n. "EU support for open access". https://ec.europa.eu/info/research-andinnovation/strategy/goals-research-and-innovation-policy/open-science/open-access_en.

Eichenbaum, M., S. Rebelo, and C. de Resende. 2017. "The Portuguese Crisis and the IMF". In Background papers on the IMF and the crises in Greece, Ireland, and Portugal, edited by M. J. Schwartz and S. Takagi, 363-447. https://doi.org/10.5089/9781475562538.017.

"Encyclical letter - Fratelli Tutti - Of the Holy Father Francis on fraternity and social friendship". 2020. https://www.vatican.va/content/francesco/en/encyclicals/documents/papafrancesco_20201003_enciclica-fratelli-tutti.html.

Fernandes, R. M. R. 2006. Memórias de um Rústico Erudito. Livros Cotovia.

Flaherty, C. 2020. "Big Proctor: Is the fight against cheating during remote instruction worth enlisting third-party student surveillance platforms?". Inside Higher Ed, May 11, 2020. https://www.insidehighered.com/news/2020/05/11/online-proctoring-surging-duringcovid-19.

Fogel, R. W. 1999. "Catching up with the economy". American Economic Review 89, no. 1: 121. https://doi.org/10.1257/aer.89.1.1.

Frølich, N., K. Wendt, I. Reymert, S. M. Tellmann, M. Elken, S. Kyvik, A. Vab $\varnothing$, and E. Larsen. 2018. Academic career structures in Europe: Perspectives from Norway, Denmark, Sweden, Finland, the Netherlands, Austria and the UK. NIFU Report; 2018:4. Nordic Institute for Studies in Innovation, Research and Education (NIFU). http://hdl.handle.net/11250/2487666.

Froyd, J. E., P. C. Wankat, and K. A. Smith. 2012. "Five major shifts in 100 years of Engineering Education". Proceedings of the IEEE 100: 1344-60. https://doi.org/10.1109/JPROC.2012.2190167.

Gibbs, B. 2020. "What are we learning about assessment?". In Emerging stronger: Lasting impact from crisis innovation, edited by B. Gibbs and G. C. Wood, 3-17. Godalming: Engineering Professors' Council.

Grave-Resendes, L., and A. Nunes. 1998. "Open and distance education in Portugal". In The TEEODE Project. Technology Enhanced Evaluation in Open and Distance Learning. Introduction to Open and Distance Education, edited by A. R. Bartolomé and J. D. M. Underwood, 32-49. Laboratori de Mitjans Interactius, University of Barcelona. http://www.Imi.ub.es/teeode/THEBOOK/files/portugue/html/5port.htm.

Grugeon, D., and K. Tibbenham. 1980. "Teaching at a Distance: a selective survey of articles from issues 1-16". Distance Education 1, no. 1: 92-98. https://doi.org/10.1080/0158791800010106.

Gurtin, M. E. 2004. "2004 Timoshenko medal acceptance speech by Morton E. Gurtin". https://imechanica.org/node/197. 
Hall, R. 2017. "Why should I care about the teaching excellence framework? - explainer". Guardian, June 19, 2017. https://www.theguardian.com/higher-educationnetwork/2017/jun/19/why-should-i-care-about-the-teaching-excellence-frameworkexplainer.

Hamad, J. A., M. Hasanain, M. Abdulwahed, and R. Al-Ammari. 2013. "Ethics in engineering education: A literature review". Paper presented in IEEE Frontiers in Education Conference, Oklahoma City, USA, October 2013. https://doi.org/10.1109/FIE.2013.6685099.

Hambling, D. 2021. "Cloud control". New Scientist 249, no. 3326: 41-43. https://doi.org/10.1016/S0262-4079(21)00475-9.

Heitor, M., J. M. B. de Brito, and M. F. Rollo, eds. 2004. Momentos de Inovação e Engenharia em Portugal no Século XX. 3 vols. Dom Quixote.

Heitor, M., J. M. B. de Brito, M. F. Rollo, H. Cayatte, J. Pessoa, and R. Trindade, eds. 2003. Engenho e obra: Memória de uma exposição. Dom Quixote.

Hirsch, J. E. 2005. "An index to quantify an individual's scientific research output". Proceedings of the National Academy of Sciences of the United States of America 102, no. 46: 1656972. https://doi.org/10.1073/pnas.0507655102.

Human Readers. 2013. "Professionals against machine scoring of student essays in high-stakes assessment". http://humanreaders.org/petition/.

loannidis, J. P. A., J. Baas, R. Klavans, and K. W. Boyack. 2019. "A standardized citation metrics author database annotated for scientific field". PLOS Biology 17, no. 8: Article number e3000384. https://doi.org/10.1371/journal.pbio.3000384.

Kaplan, N. 1963. "Scientists in Industry: Conflict and Accomodation. By William Kornhause, Warren O. Hagstrom". American Sociological Review 28, no. 6: 1042-43. https://doi.org/10.2307/2090324.

Katz, S. N. 2002. Can Research Universities Teach Undergraduates Effectively?: Woodrow Wilson School [syllabus WWS 401a, Fall Term]. https://scholar.princeton.edu/sites/default/files/snkatz/files/wws401a_f02.pdf.

Keller, G. 1983. Academic strategy: The management revolution in American Higher Education. The Johns Hopkins University Press.

Kemp, A. T. 2013. "Collaboration vs. Individualism: What is better for the rising academic?". The Qualitative Report 18, no. 50: 1-8. https://doi.org/10.46743/2160-3715/2013.1429.

Kerr, C. 2001. The uses of the University. $5^{\text {th }}$ ed. Harvard University Press.

Koltun, V., and D. Hafner. 2021. "The h-index is no longer an effective correlate of scientific reputation". Preprint, submitted February 5, 2021. https://arxiv.org/abs/2102.03234.

Krathwohl, D. R., B. S. Bloom, and B. B. Masia. 1964. Taxonomy of Educational Objectives: Handbook II - Affective Domain. David McKay Company, Inc.

Krause, S. D., and C. Lowe, eds. 2014. Invasion of the MOOCs: The promises and perils of Massive Open Online Courses. Parlor Press.

Latoeiro, P., and F. Domingues. 2021. O mundo não tem de ser assim: Biografia de António Guterres. Casa das Letras.

Les 100 Meilleures Universites en Europe. 1989. Libération.

Liang, C., and H.-T. Yeh. 2014. "The influences of personality traits on academic performance through imaginative capability: the differences between engineering and science". In Engineering Education: Curriculum, Pedagogy and Didactic Aspects, edited by J. P. Davim, 1-23. Chandos Publishing. https://doi.org/10.1533/9781780633589.1. 
Lidicker Jr., W. Z. 2020. "A scientist's warning to humanity on human population growth". Global Ecology and Conservation 24: Article number e01232. https://doi.org/10.1016/j.gecco.2020.e01232.

Lima, R. M., and D. Mesquita. 2018 "Engineering Education (Res earch) in European Countries - An overview based on publications in journals". Paper presented at the $3^{\text {rd }}$ International Conference of the Portuguese Society for Engineering Education (CISPEE), Aveiro, Portugal, June 2018. https://doi.org/10.1109/CISPEE.2018.8593489.

List of Engineering Education Journals. 2015. Engineering Education Enhancement and Research Asia (E3R Asia). https://tlerg.cetl.hku.hk/wp-content/uploads/2017/03/e3rinserts-list.pdf.

Lodge, D. 1984. Small world: An academic romance. Penguin Books.

Malthus, T. R. 1826. An essay on the principle of population. $6^{\text {th }}$ ed. John Murray.

Marope, P. T. M., P. J. Wells, and E. Hazelkorn, eds. 2013. Rankings and accountability in Higher Education - Uses and misuses. UNESCO. https://unesdoc.unesco.org/ark:/48223/pf0000220789.

Meadows, D. H., D. L. Meadows, J. Randers, and W. W. Behrens III. 1972. The limits to growth: A report for the club of Rome's project on the predicament of mankind. A Potomac Associates Books. Universe Books.

Merton, R. K. 1947. "The machine, the worker, and the engineer". Science 105, no. 2717: 7984. https://doi.org/10.1126/science.105.2717.79.

Merton, R. K. 1968. Social theory and social structure. New York: Free Press.

Mintz, S. 2017. "11 lessons from the history of Higher Ed: Envisioning the future". Inside Higher Ed, May 7, 2017. https://www.insidehighered.com/blogs/higher-ed-gamma/11-lessonshistory-higher-ed.

Mitcham, C. 2009. "A historico-ethical perspective on engineering education: from use and convenience to policy engagement". Engineering Studies 1, no. 1: 35-53. https://doi.org/10.1080/19378620902725166.

Mónica, M. F. 2013. "A Universidade". XXI, Ter Opinião, $2^{\text {nd }}$ semester, 148-51. https://www.ffms.pt/artigo/419/a-universidade.

National Academy of Sciences, National Academy of Engineering, and Institute of Medicine. 2014. The arc of the academic research career: Issues and implications for U.S. science and engineering leadership: Summary of a workshop. Edited by B. L. Benderly. Washington, DC: The National Academies Press. https://doi.org/10.17226/18627.

NC State University, and College of Engineering. n.d. "Richard Felder's Legacy Website". https://www.engr.ncsu.edu/stem-resources/legacy-site/.

Nieto, A. 1989. "A tribo universitária - Actividades académicas de um catedrático". Revista Crítica de Ciências Sociais no. 27/28: 275-82. Special issue published on the 700 years of the Universidade de Coimbra. https://www.ces.uc.pt/publicacoes/rccs/artigos/27\%20\%2028/Alejandro\%20Nieto\%20-\%20A\%20Tribo\%20Universitaria\%20\%20Actividades\%20Academicas\%20do\%20Catedratico.pdf.

NSPE-National Society of Professional Engineers. n.d. "Frequently asked questions about engineering". https://www.nspe.org/resources/press-room/resources/frequently-askedquestions-about-engineering.

Oakeshott, M. 2004. "The idea of a University". Academic Questions 17, no. 1: 23-30. https://doi.org/10.1007/s12129-003-1045-3. 
Orwell, G. 1949. Nineteen Eighty-Four: A Novel. $1^{\text {st }}$ ed. Secker \& Warburg.

Pan, R. K., A. M. Petersen, F. Pammolli, and S. Fortunato. 2018. "The memory of science: Inflation, myopia, and the knowledge network". Journal of Informetrics 12, no. 3: 656-78. https://doi.org/10.1016/j.joi.2018.06.005.

Pearce, S. 2019. Independent review of the teaching excellence and student outcomes framework (TEF): Report to the Secretary of State for Education. https://www.gov.uk/government/publications/independent-review-of-tef-report.

Petroski, H. 2010. "Engineers and scientists: similarities and differences". The Bent of Tau Beta Pi (Summer): 22-26. https://www.tbp.org/pubs/Features/Su10Petroski.pdf.

Plovnick, M. S. 1972. Social awareness and role innovation in engineers. Working paper (Sloan School of Management); 604-72. MIT - Massachusetts Institute of Technology. http://hdl.handle.net/1721.1/49123.

PORDATA. 2019. "Despesas em actividades de investigação e desenvolvimento (I\&D) em \% do PIB: $\quad$ por sector de execução". https://www.pordata.pt/Portugal/Despesas+em+actividades+de+investiga\%C3\%A7\%C3\% $\mathrm{A} 30+\mathrm{e}+$ desenvolvimento+(I+D)+em+percentagem+do+PIB+por+sector+de+execu\%C3\%A7 \%С3\%A30-1133.

QAA-Quality Assurance Agency for Higher Education. 2018. UK quality code for Higher Education. Advice and guidance. Assessment. https://www.qaa.ac.uk/quality-code/adviceand-guidance/assessment.

Ramos, M. J. 2020. "A universidade sem professores". Público, March 12, 2020. https://www.publico.pt/2020/03/12/sociedade/opiniao/universidade-professores1907339.

Reid, C. N., C. W. A. Newey, K. A. Reynolds, G. Weaver, and K. Williams. 1978. "A case study approach to teaching fracture". In Advances in Research on the Strength and Fracture of Materials - Fourth International Conference on Fracture, 429-42. Pergamon Press. https://doi.org/10.1016/B978-0-08-022136-6.50036-6.

Reilly, E. D., R. E. Stafford, K. M. Williams, and S. B. Corliss. 2014. "Evaluating the validity and applicability of automated essay scoring in two massive open online courses". The International Review of Research in Open and Distributed Learning 15, no. 5: 83-98. https://doi.org/10.19173/irrodl.v15i5.1857.

"Relatos das sessões de trabalho". 1962. Paper presented in Congresso do Ensino de Engenharia, Lisboa, Portugal.

Renouard, M. 2016. Fragments d'une mémoire infinie. Grasset.

- - 2017. "Nouveaux fragments d'une mémoire infinie". Esprit, Mars/Avril. https://esprit.presse.fr/article/mael-renouard/nouveaux-fragments-d-une-memoireinfinie-39257.

- 2020. "To infinity and beyond". Harper's Magazine, May. https://harpers.org/archive/2020/05/to-infinity-and-beyond-mael-renouard/.

Ribeiro, J. F. 2020. Economia, Tecnologias e Engenharia - Contributo para uma Reflexão Estratégica da FEUP com o Horizonte 2037. Edited by A. T. Marques and C. C. de Oliveira. FEUP. https://bit.ly/EconomiaTecnologiasEngenharia.

Rodrigues, J. N., and T. Devezas. 2009. Pioneers of globalization: Why the Portuguese surprised the world. $2^{\text {nd }}$ ed. Edições Centro Atlântico.

Rosovsky, H. 1990. The University: An owner's manual. W. W. Norton \& Company. 
Rosovsky, H., and M. Hartley. 2002. Evaluation and the academy: Are we doing the right thing? Grade inflation and letters of recommendation. American Academy of Arts and Sciences. https://www.amacad.org/sites/default/files/publication/downloads/Evaluation_and_the _Academy.pdf.

Santos, F. D. 2020. "O acordo de Paris e a geoengenharia". In Memórias da Academia das Ciências de Lisboa. Classe de Ciências, 127-37. Academia das Ciências de Lisboa.

- - . 2021. Time, progress, growth and technology: How humans and the earth are responding. Springer. https://doi.org/10.1007/978-3-030-55334-0.

Schumacher, E. F. 1975. Small is beautiful: A study of economics as if people mattered. $5^{\text {th }}$ reprint. Blond \& Briggs Ltd.

Schwartz, M. J., and S. Takagi. 2017. Background papers on the IMF and the crises in Greece, Ireland, and Portugal. IMF. https://doi.org/10.5089/9781475562538.017.

Shanti, M. 2017. "Campus fiction - A critical study". PhD diss., Goa University. http://hdl.handle.net/10603/273223.

Shay, S. 2018. "Rethinking university rankings: We need to talk about quality (and inequality) of teaching". The Conversation, October 3, 2018. https://theconversation.com/rethinking university-rankings-we-need-to-talk-about-quality-and-inequality-of-teaching-104071.

Shoaff-Ballanger, S. M., and D. J. Davis. 1992. "Professional conferences for Art Educators: A pilgrimage to excellence". Art Education 45, no. 4: 37-44. https://doi.org/10.1080/00043125.1992.11652934.

Sianipar, C. P. M., G. Yudoko, K. Dowaki, and A. Adhiutama. 2013. "Design methodology for appropriate technology: engineering as if people mattered". Sustainability 5, no. 8: 3382425. https://doi.org/10.3390/su5083382.

SIC. 2020. "News September 18, 2020" [circa 22h40].

Simpson, I. H. 1972. "'The Professions: Roles and Rules' by Wilbert E. Moore in collaboration with Gerald W. Rosenblum". Social Forces 50, no. 3: 407-08. https://doi.org/10.1093/sf/50.3.407-a.

Squazzonia, F., G. Bravo, and K. Takács. 2013. "Does incentive provision increase the quality of peer review? An experimental study". Research Policy 42, no. 1: 287-94. https://doi.org/10.1016/j.respol.2012.04.014.

Stewart, T. 2006. "Teacher-researcher collaboration or teachers' research?". TESOL Quarterly 40, no. 2: 421-29. https://doi.org/10.2307/40264529.

Temple, P. 2018. "Academic strategy: The management revolution in American Higher Education, by George Keller (1983). Can strategy work in higher education?". Higher Education Quarterly 72, no. 2: 170-77. https://doi.org/10.1111/hequ.12160.

Teoh, R., U. Schumann, A. Majumdar, and M. E. J. Stettler. 2020. "Mitigating the climate forcing of aircraft contrails by small-scale diversions and technology adoption". Environmental Science \& Technology 54, no. 5: 2941-50. https://doi.org/10.1021/acs.est.9b05608.

The Economist. 2020. "How France created a university to rival MIT". August 29, 2020. https://www.economist.com/e urope/2020/08/29/how-france-created-a-university-torival-mit.

Trindade, A. R. 2005. "The salami concept". Educação a distância: percursos: 41-42. http://hdl.handle.net/10400.2/251. 
Trumbul, E., C. Rothstein-Fisch, and P. M. Greenfield. 2000. Bridging cultures in our schools: New approaches that work. WestEd. https://www.wested.org/resources/bridgingcultures-in-our-schools-new-approaches-that-work-knowledge-brief/\#.

"Uni-test Europa. Spiegel serie: Studieren ohne Grenzen". 1998. Der Spiegel, May 4, 1998. https://www.spiegel.de/spiegel/print/index-1998-19.html\#inhaltsverzeichnis.

Valcke, M., and M. Thorpe. 1995. "Distance education: A particular context for teaching and learning. Introduction to this special issue". European Journal of Psychology of Education 10, no. 2: 111-19. https://doi.org/10.1007/BF03172909.

Van Noorden, R., and D. S. Chawla. 2019. "Policing self-citations: some top academics cite themselves heavily, and researchers are debating what to do about it". Nature 572: 57879.

Vest, C. M. 2008. "Engineering education for the $21^{\text {st }}$ Century". Paper presented in ASEE Annual Conference, Pittsburgh, PA, June 2008. https://slidetodoc.com/engineering education-for-the-21-st-century-charles/.

Wankat, P. C., and F. S. Oreovicz. 1993. Teaching Engineering. McGraw-Hill.

Williams, K. 1989. "The gift of an interval: Michael Oakeshott's idea of a university education". British Journal of Educational Studies 37, no. 4: 384-97. https://doi.org/10.2307/3121347.

Willoughby, K. W. 1990. Technology choice: A critique of the appropriate technology movement. Westview Press.

Yáñez-Arancibia, A., J. W. Day, C. A. S. Hall, and E. Reyes. 2013. "Diminished resources, energy scarcity and climate change: Unsustainable future development". In Ecological Dimensions for Sustainable Socio Economic Development, edited by A. Yáñez-Arancibia, R. DávalosSotelo, J. W. Day, and E. Reyes, 557-74. Southampton, UK: WIT Press.

\section{Acronyms}

AAAS American Association for the Advancement of Science

ABET Accreditation Board for Engineering and Technology

$A D \quad$ anno domini

Al artificial intelligence

AIAA American Institute of Aeronautics and Astronautics

aka also known as

ARWU Academic Ranking of World Universities (aka Shanghai Ranking)

ASCE American Society of Civil Engineers

ASEE American Society for Engineering Education

ASME American Society of Mechanical Engineers

BPPE Board on Professional Practice and Ethics (ASME)

CalTech California Institute of Technology

CDIO conceiving, designing, implementing, operating

CSU California State University

CVCP Committee of Vice-Chancellors and Principals of the Universities of the UK

E4C Engineering for Change

EADTU European Association of Distance Teaching Universities

ECTS European Credit Transfer and Accumulation System 


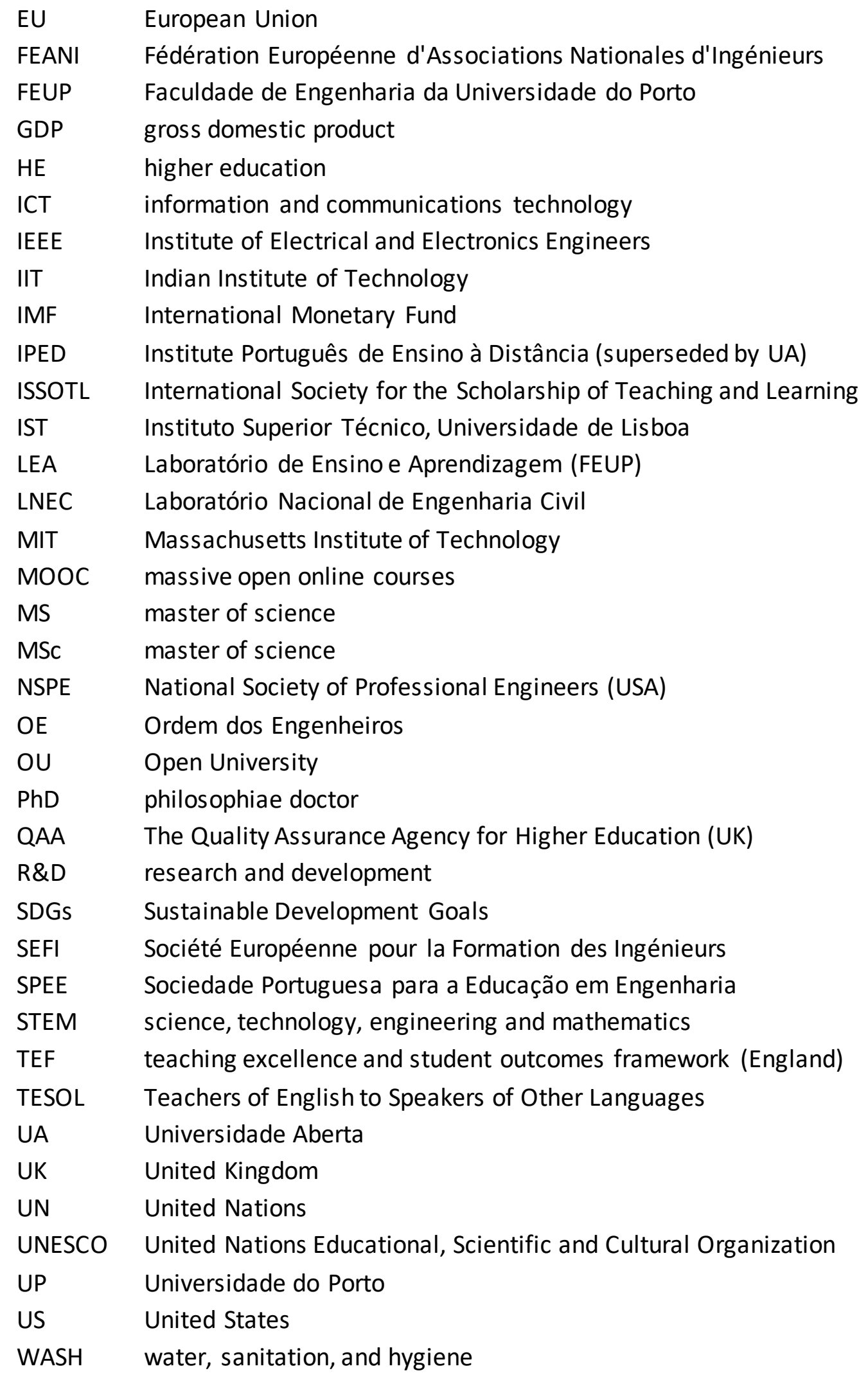

